\title{
Redefinition of the parastenocaridid genus Proserpinicaris (Copepoda: Harpacticoida), with description of three new species from Korea
}

\author{
Tomislav Karanovic ${ }^{\mathrm{a}, \mathrm{b} *}$, Joo-Lae $\mathrm{Cho}^{\mathrm{c}}$ and Wonchoel Lee ${ }^{\mathrm{a}}$ \\ ${ }^{a}$ Hanyang University, Department of Life Sciences, 17 Haengdang-dong, Seongdong-gu, Seoul \\ 133-791, Korea; ${ }^{b}$ University of Tasmania, Institute for Marine and Antarctic Studies, Cnr \\ Alexander and Grosvenor Sts, Private Bag 129, Hobart, Tasmania 7001, Australia; ${ }^{c}$ National \\ Institute of Biological Resources, Environmental Research Complex, Gyoungseo-dong, Seo-gu, \\ Incheon 404-708, Korea
}

(Received 8 August 2011; final version received 28 March 2012; printed 14 June 2012)

\begin{abstract}
Proserpinicaris young sp. nov., Proserpinicaris wangpi sp. nov. and Proserpinicaris imjin sp. nov. are described from subterranean waters of South Korea. They are short-range endemics, allopatric in distribution and closely related to each other, and to two other Far Eastern congeners. Distinguishing features are limited to the general habitus shape, proportions of the caudal rami and degree of sexual dimorphism. The genus Proserpinicaris Jakobi, 1972, as redefined here, is Palaearctic in distribution, with the centre of diversity in southern Europe, and 20 valid members, all of which share a large hyaline spiniform structure on the male fourth leg basis as a synapomorphy. A key to species is provided. Genera Niponnicaris Jakobi, 1972 and Pannonicaris Jakobi, 1972 are established as its junior subjective synonyms, Lacustricaris Jakobi, 1972 is formally synonymized with Parastenocaris Kessler, 1913, and Parastenocaris lacustris Chappuis, 1958 is designated as incertae sedis in Fontinalicaridinae Schminke, 2010.
\end{abstract}

Keywords: taxonomy; systematics; stygofauna; phylogeny; zoogeography; endemism

\section{Introduction}

Parastenocarididae Chappuis, 1940 is a harpacticoid family highly specialized for life in continental groundwater, and almost exclusively restricted to this habitat (Galassi and De Laurentiis 2004). Its members are, however, distributed on all continents except Antarctica and New Zealand (Karanovic 2004), which is remarkable considering that stygofauna has a limited active dispersal potential and lacks resting stages that could be dispersed passively (Culver and Pipan 2009). Because parastenocaridids have no marine relatives or modern pathways between different continents (Boxshall and Jaume 2000), it has been postulated that they have a Pangean origin (Karanovic 2006). In Australia, for example, Karanovic (2004) speculated that they started colonizing subterranean waters just after the Permo-Carboniferous glaciation, which spread throughout much of what subsequently became the Gondwana supercontinent and covered the entire Australian plate (Frakes 1999; Playford 2003). This makes it likely that present distributions of most parastenocaridids are a result of continental

\footnotetext{
*Corresponding author. Email: Tomislav.Karanovic@utas.edu.au
} 
drift (Boxshall and Jaume 2000), and so an ideal group to study vicariance models in zoogeography. Unfortunately, no research has been done on their phylogeography so far, except for three genera from Australia (Karanovic and Cooper, 2011a).

The family is a monophyletic group within Harpacticoida, being easily distinguished by the sexual dimorphism in the third pair of swimming legs (Corgosinho et al. 2007). Modification of these legs in males into a grasping organ that allows them to hold females during copulation (Glatzel and Schminke 1996), is one of the most important synapomorphies of the group (Martinez Arbizu and Moura 1994), but many other morphological characters make it very easy to instantly recognize its members (Karanovic and Cooper, 2011a). However, a great number of morphological characters are conservative within this family, making generic division a real and long-lasting problem (Reid 1995; Galassi and De Laurentiis 2004; Karanovic 2005; Schminke 2010), and the family stayed monogeneric for a long time despite a steady accumulation of new species.

Chappuis (1937) divided its only genus Parastenocaris Kessler, 1913 into four groups, which he numbered rather than named, each containing two species. Kunz (1938) added another group. Lang (1948) subdivided the family into eight speciesgroups for 31 of the 40 species known at that time (nine species were either known only as females or were insufficiently described), accepting the group proposed by Kunz (1938), but rearranging three of those proposed by Chappuis (1937) and naming them after the most characteristic species. For diagnosing all these groups all three authors mostly used characters of the male fourth leg endopod. Despite being chiefly based on a single character, Lang's system was widely accepted and was coping rather well with a subsequent steady influx of newly described species from around the world, culminating in the decade between 1963 and 1972 when 75 new species were added (Schminke 2010). Five new species groups were added subsequently by Noodt $(1962,1963,1972)$, mostly for the newly discovered and very diverse South American fauna, but it became apparent that this increasingly more complex system of species groups was not a reflection of true phylogenetic relationships, which were not taken into account in the description of many of the new taxa.

Jakobi (1969) described one of Noodt's groups as a new genus, and it was Jakobi (1972) who made the first effort to revise the family by splitting it into 26 different genera, although only assigning to them 98 of the 155 known species. This system was strongly criticized by Schminke (1976), and was ignored for a long time by most subsequent taxonomists working on this group, all of them accepting only two of Jakobi's genera (see Por and Hadel 1986; Dussart and Defaye 1990; Reid 1995; Karanovic and Bobic 1998; Ranga Reddy 2001; Galassi and De Laurentiis 2004; Boxshall and Halsey 2004; Karanovic 2005, 2006; Cottarelli et al. 2006, 2007, 2008; Wells 2007; Ranga Reddy and Defaye 2007, 2009; Huys 2009). In a few isolated cases Jakobi's genera were treated as subgenera (see Kiefer 1976). Jakobi (1972), for example, divided the brevipes-group of Lang (1948) into five different genera, which was shown by Reid (1995) to be a group of very closely related species. Reid (1995) even demonstrated that the type species of one new genus proposed by Jakobi is in fact a junior subjective synonym of the type species of Parastenocaris. Nevertheless, new genera were proposed for some unusual new members from South America (Dussart 1979; Reid 1994), Europe (Galassi and De Laurentiis 2004), Africa (Schminke 2009), Asia (Cottarelli et al. 2010), and Australia (Karanovic and Cooper, 2011a), and two more groups of species were proposed by Berera and Cottarelli (2003) and Galassi and De Laurentiis 
(2004). Recently, some researchers (Corgosinho and Martinez Arbizu 2005; Schminke 2008; Corgosinho et al. 2010) started to redefine some genera originally proposed by Jakobi (1972), as most of them remained valid and available names under the rules of the ICZN (1999), while at the same time synonymizing some others.

The latest family revision was published by Schminke (2010), who listed all 258 species described until then in the family Parastenocarididae, provisionally accepted 27 genera as valid (accepting most of those described by Jakobi, although mainly listing just their type species as valid members), and subdivided the family into two subfamilies. As a result of the Principle of Coordination, Parastenocaridinae Chappuis, 1940 has already (potentially) existed since 1940, with Parastenocaris as its type genus. In that respect, "Parastenocaridinae nov.", which was Schminke's most frequent way to refer to the taxon (Schminke 2010), is an error. He does, however, correctly call it "Parastenocaridinae Chappuis, 1940" in three places in his paper. On the other hand, he seems reluctant to call these two groups subfamilies, putting the word "subfamily" in quotes in the abstract and noting that such subgroups as he is proposing are "traditionally called subfamilies" (p. 344). Besides these instances, he does not use the term subfamily in the diagnosis section (pp. 361-362) or anywhere else. Still, the above quoted notation on p. 344, together with the frequent notation "nov.", is enough to show that he is intentionally proposing a new taxon (Fontinalicaridinae) of subfamily rank (i.e. it is not an informal or "provisional" or Phylocode-type unavailable taxon), and he explicitly designates its type genus. Therefore, we think, he has (barely) met the requirements for availability of new names. Mainly because of incomplete descriptions or absence of males, he was able to classify only 112 species of Parastenocarididae to the genus level, leaving a majority of them in the genus Parastenocaris. Division of the genus Parastenocaris into Parastenocaris s. str. and Parastenocaris s. l., as first proposed by Galassi and De Laurentiis (2004) and adopted with a different meaning by Schminke (2010), has neither nomenclatural bearing nor phylogenetic justification, as sensu stricto by definition must be part of sensu lato.

We redefine here the genus Proserpinicaris Jakobi, 1972 based on synapomorphic character states found in a group of 20 closely related species, including three new short-range endemics from South Korea. Although technically this may be seen in stark contrast to Schimnke's monospecific concept of this genus (Schminke 2010), we actually build on his work and use many morphological characters recognized by him as phylogenetically informative. It was Kunz (1938) who first recognized that the Italian Parastenocaris proserpina Chappuis, 1938 is quite distant from the type species of the genus, and he proposed a separate group of species ("proserpina-Gruppe") for it and two other closely related congeners: the Spanish P. cantabrica Chappuis, 1937, and the German $P$. phyllura Kiefer, 1938; the latter species was subsequently found throughout central and northern Europe (see Enckel 1969). Lang (1948) acknowledged this group and added two more species: the Hungarian P. budapestiensis Török, 1935, and the German P. nolli Kiefer, 1938. Although his action regarding P. budapestiensis may be explained by a probable mix-up in the original drawings of Török (1935) (see below), both species seem to be only remotely related to those included by Kunz (1938). Jakobi (1972) erected the genus Proserpinicaris for this group of species, with $P$. proserpina as its type species, recognized $P$. cantabrica, $P$. phyllura and $P$. nolli as its valid members, and included two other species that were described after Lang (1948): the Czech P. moravica Šterba, 1965, and the Canadian P. delamarei Chappuis, 1958. 
He listed the publication date of the latter species erroneously as 1957, but $P$. delamarei was described in Chappuis and Delamare Debouteville (1958). Jakobi (1972) excluded $P$. budapestiensis from this group and designated it the type species of his new genus Lacustricaris Jakobi, 1972, where he included additionally only the Canadian P. lacustris Chappuis, 1958 (also with the incorrect publication date of 1957). Schminke (2010) considered P. budapestiensis as incertae sedis in Parastenocaridinae, whereas he listed Lacustricaris as a valid member of Fontinalicaridinae, and with L. lacustris (Chappuis, 1958) as its only member. This action is completely unjustified under the rules of the ICZN (1999), and may be a simple lapsus calami. We argue below that $P$. budapestiensis, $P$. nolli and $P$. delamarei are not at all closely related to the type species of Proserpinicaris, while $P$. cantabrica, $P$. phyllura and $P$. moravica are.

\section{Materials and methods}

Specimens of three new species described here were collected either using the Karaman-Chappuis method (digging a hole in the sand bank and decanting water through a plankton net), or with a phreatic pump. In all cases 100 litres of water was filtered, so quantitative data were obtained. All samples were fixed in $99.9 \%$ ethanol. Locality data and number of specimens are listed for every species separately and all types are deposited in the National Institute of Biological Resources (NIBR), Seoul.

Specimens were dissected and mounted on microscope slides in Faure's medium, which was prepared following the procedure discussed by Stock and von Vaupel Klein (1996), and dissected appendages were then covered by a coverslip. For the urosome or the entire animal two human hairs were mounted between the slide and coverslip, so the parts would not be compressed. By manipulating the coverslip carefully by hand, the whole animal or a particular appendage could be positioned in different aspects, making possible the observation of morphological details. During the examination water slowly evaporates and appendages eventually remained in a completely dry Faure's medium, ready for long-term depositing. All line drawings were prepared using a drawing tube attached to a Leica MB2500 phase-interference compound microscope, with N-PLAN $(5 \times, 10 \times, 20 \times, 40 \times$ and $63 \times$ dry $)$ or PL FLUOTAR $(100 \times$ oil $)$ objectives. Specimens that were not drawn were examined in propylene glycol $\left(\mathrm{CH}_{3} \mathrm{CH}(\mathrm{OH}) \mathrm{CH}_{2} \mathrm{OH}\right)$ and, after examination, were again preserved in $99.9 \%$ ethanol. Specimens for the scanning electron micrography were dehydrated in progressive ethanol concentrations, critical-point dried, coated in gold and observed under a LEO 1525 microscope on the in-lens detector, with working distances between 5.9 and $6.1 \mathrm{~mm}$ and accelerating voltages of 5 or $10 \mathrm{kV}$.

Morphological terminology follows Huys and Boxshall (1991), except for caudal ramus setae numbering (major reasons being that they did not study caudal rami of parastenocaridid copepods, and nobody so far has provided any conclusive evidence on the homology of different caudal armature elements in different copepod orders) and small differences in the spelling of some appendages (antennula, mandibula, maxillula instead of antennule, mandible, maxillule), as an attempt to standardize the terminology for homologous appendages in different crustacean groups. Biospeleological terminology follows Humphreys (2000). Descriptions of second and third new species were shortened by making them comparative, and only the first species is described here in full. 


\title{
Systematics
}

\author{
Subphylum CRUSTACEA Brünnich, 1772 \\ Class MAXILLOPODA Dahl, 1956 \\ Subclass COPEPODA H. Milne Edwards, 1840 \\ Order HARPACTICOIDA G.O. Sars, 1903 \\ Family PARASTENOCARIDIDAE Chappuis, 1940 \\ Subfamily FONTINALICARIDINAE Schminke, 2010 \\ Genus Proserpinicaris Jakobi, 1972
}

Synonyms

Nipponicaris Jakobi, 1972, syn. nov.; Pannonicaris Jakobi, 1972 syn. nov.

Type species

Parastenocaris proserpina Chappuis, 1938.

Other species

Parastenocaris admete Cottarelli, Fasano, Mura and Saporito, 1980; P. amalasuntae Bruno and Cottarelli, 1998; P. cantabrica Chappuis, 1937; P. cruzi Noodt and Galhano, 1969; P. fontinalis meridionalis Rouch, 1990; P. gorganensis Kovalchuk and Kovalchuk, 1990; P. hispanica Martínez Arbizu, 1997; P. ima Cottarelli, 1989; P. imjin sp. nov.; P. kalypso Pesce, Galassi and Cottarelli, 1988; P. mangini Rouch, 1992; P. moravica Šterba, 1965; P. nicolasi Rouch, 1996; P. nipponensis Chappuis, 1955; P. ondali Lee and Chang, 2009; P. pannonica Török, 1935; P. phyllura Kiefer, 1938; $P$. wangpi sp. nov.; P. young sp. nov.

\section{Revised diagnosis}

Small to medium-sized Fontinalicaridinae, with cylindrical habitus, smooth cuticule, somites ornamented with large sensilla, and with dorsal cuticular windows on cephalothorax and all urosomal somites, except first and last; spinules, if present at all, usually restricted to anal somite. Podoplean boundary between prosome and urosome inconspicuous. Genital complex in female occupying anterior ventral half of genital double somite; genital apertures and median copulatory pores covered by vestigial sixth legs, fused completely into relatively narrow flap. Caudal rami cylindrical or leaf-like, with lateral cuticular pore near posterior margin, armed with seven elements (three lateral, one dorsal, and three apical); lateral elements inserted close to each other and much more anteriorly than dorsal seta; one lateral element minute and hard to observe between two others. Male antennula eight-segmented, prehensile, with geniculation between third and fourth and sixth and seventh segments; last two segments in line; distal anterior corner of seventh segment produced into very small spiniform process, but larger proximal spiniform process present on fifth segment on anterior surface; aesthetasc on fifth segment usually massive and reaching tip of appendage. First swimming leg with no chitinous processes or inner basal armature. Second swimming leg with one-segmented endopod, armed with single slender seta apically, and with several apical spinules and sometimes with several lateral spinules. Third swimming leg endopod in female very small and linguiform segment 
unarmed, usually with few apical spinules. Third swimming legs in male transformed into strong grasping organs, with large intercoxal sclerite between them, each composed of praecoxa, coxa, basis, two-segmented exopod, and endopod reduced to single slender armature element; basis and proximal exopodal segment robust, latter usually with beaks or chitinous lobes on inner margin; outer spine on first exopodal segment smooth, large, and curved; ancestral distal exopodal segment (apophysis) small, usually cylindrical, oriented slightly inwards, unornamented, and armed with single short element on top, often leaf-like, or thumb-like. Fourth swimming leg in male with or without spinules on inner margin of coxa, but always with large and slender hyaline process on anterior surface of basis, between exopod and endopod, and no other chitinous structures on basis; first exopodal segment with longitudinal row of strong spinules on inner margin, and no other structures or depressions on this margin; endopod one-segmented, with or without apical armature, but usually curved and variously transformed, often knife-like (with serrated edges or tubercules), rarely pinnate, sometimes with scoop-like structure on tip. Fourth swimming leg in female without hyaline process on basis or inner spinules on first exopodal segment; endopod also one-segmented but cylindrical, straight, and not transformed, with strong element on tip, several apical spinules, and several spinules around midlength close to inner margin. Fifth legs very similar in shape in male and female, elongated and simple triangular plates, with inner distal corner produced into spiniform process, ornamented with spinules along inner margin (these often absent in female), usually another row of spinules on posterior surface proximally, and single large cuticular pore on anterior surface; armature consists of very long outermost seta (ancestral basal); two setae at outer base of inner distal process (probably ancestral endopodal setae), and sometimes small seta (or long spinule?) on posterior surface at base of basal seta; latter element most often reduced to minute spiniform process and hardly visible (smaller than most spinules). Sixth legs in male also fused (or right one reduced and left one enlarged?) smooth, unarmed, unornamented, forming simple operculum covering gonopore.

\section{Remarks}

Fourth swimming leg in male with a large and slender hyaline process on the anterior surface of basis, between exopod and endopod, being the sole chitinous structure on this segment, is a synapomorphy that unites all species included in the currently redefined genus Proserpinicaris Jakobi, 1972. Most other characters can be found in some other Fontinalicaridinae genera, or species of Parastenocaris Kessler, 1913 that are currently considered to be members of this subfamily by Schminke (2010) (see the Introduction section above). Their affinities are further discussed in the Discussion section below. Endopod of the fourth swimming leg in male is usually lanceolate or knife-like, with serrated margins, except in Proserpinicaris ima (Cottarelli, 1989) comb. nov., where it is completely smooth, and in P. cruzi (Noodt and Galhano, 1969) comb. nov. and P. cantabrica (Chappuis, 1937), where the endopod is pinnate (or plumose) along inner margin. We believe both conditions are secondary transformations, because the transformed endopod with serrulate or tuberculate margins can be found in some other unrelated taxa, and so is probably a plesiomorphic character state. All five Asian species have the endopod of the fourth leg in male with a scoop-like structure, formed by a bunch of basally fused apical spinules. They include the type species of the genus Nipponicaris Jakobi, 1972, Parastenocaris nipponensis Chappuis, 1955, and unquestionably form a monophyletic group of species. They all, 
however, have a very well developed hyaline process on the anterior surface of the fourth leg basis, which is a complex structure and highly unlikely to have arisen convergently a number of times. That is why we synonymize the genus Nipponicaris with Proserpinicaris.

The original description of Parastenocaris pannonica Török, 1935, which was designated by Jakobi (1972) as the type species of his new genus Pannonicaris Jakobi, 1972, is incomplete (see Török 1935, Lang 1948). Later redescriptions of this species by Damian (1958) and Kulhavý (1960) indicate that the large hyaline process on the fourth leg basis is between an exopod and endopod, which puts this species in the genus Proserpinicaris and renders the genus Pannonicaris its objective synonym. We speculate that the fourth leg illustrated by Török (1935) and repeated in Lang (1948) is actually a mix-up, because all other morphological details agree with those observed in Proserpinicaris. Török (1935) described two sympatric species from the Budapest water supply: P. pannonica (note: he wrongly spelled the species name as pannonicus, but being an adjective it has to agree with the feminine generic name), and $P$. budapestiensis Török, 1935. The most probable explanation is that he swapped the male fourth legs of these two species (or just their drawings during the preparation of plates), as $P$. budapestiensis also has all other typical Parastenocaridinae characters.

The genus Proserpinicaris, as defined here, is Palaearctic in distribution, with its centre of diversity in southern Europe. Note that Parastenocaris fontinalis meridionalis Rouch, 1990 was correctly considered a separate species already by Martínez Arbizu (1997), although he considered it a member of the fontinalis-group. Karanovic (2005) pointed out that this species is a member of the proserpina-group, as well as $P$. hispanica Martínez Arbizu, 1997. We discuss this further below.

\section{Proserpinicaris young sp. nov.}

(Figures 1-6)

\section{Type locality}

South Korea, Gyungsangbuk-do region, Sanggu city, Young river, interstitial water from sandy beaches on banks, $36^{\circ} 31^{\prime} 42.8^{\prime \prime} \mathrm{N}, 128^{\circ} 14^{\prime} 02.7^{\prime \prime} \mathrm{E}$.

\section{Specimens examined}

Types only: holotype male, allotype female, seven paratypes (three males and four females) together on one scanning electron microscopy stub (collection number NIBRIV0000232611); six paratypes (four males and two females) dissected on one slide each (collection numbers NIBRIV0000232612 to 0000232617); additional 36 paratypes (18 males, 11 females, and seven copepodids) together in alcohol (NIBRIV0000232618); 25 paratypes (10 males, 10 females, and five copepodids) sent for DNA barcoding; all collected from type locality, 24 April 2010, leg. J.-L. Cho, all deposited in the National Institute of Biological Resources, South Korea.

\section{Etymology}

The species name refers to its type locality, the Young river, and should be treated as a noun in apposition to the generic name. 

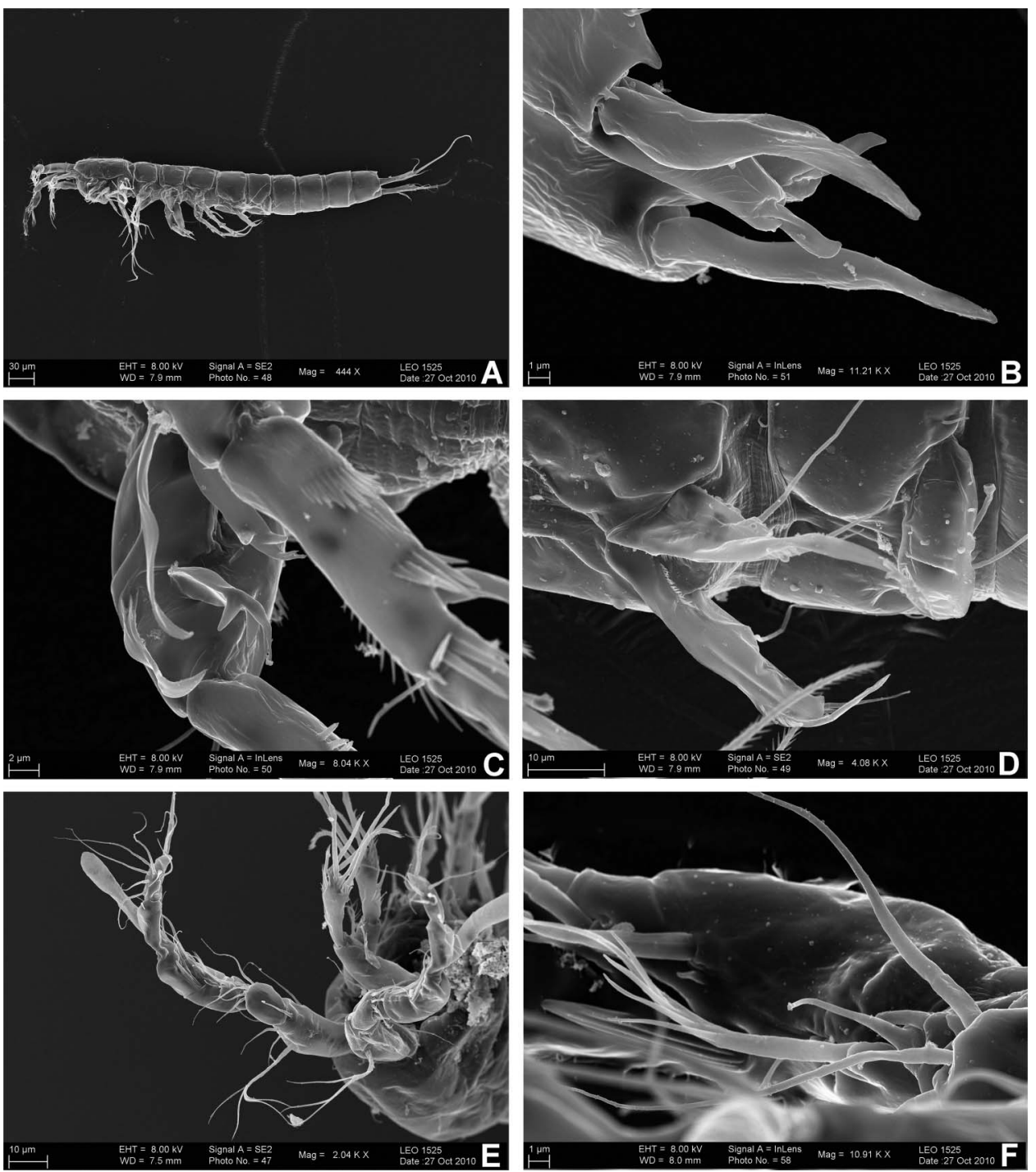

Figure 1. Proserpinicaris young sp. nov., scanning electron micrographs, (A-D) holotype male; (E) paratype male 1; (F) paratype male 2. (A) Habitus, lateral view; (B) distal tips of third swimming legs; (C) fourth swimming legs, ventrolateral view; (D) fifth and sixth legs, ventrolateral view; (E) antennulae, anterior view; (F) detail of left antennula, lateral view. Scale bars $30 \mu \mathrm{m}$ for (A), $10 \mu \mathrm{m}$ for (D, E), $2 \mu \mathrm{m}$ for (C), and $1 \mu \mathrm{m}$ for (B, F).

\section{Description}

Male (based on holotype and several paratypes). Total body length, measured from tip of rostrum to posterior margin of caudal rami (excluding caudal setae), from 375 to $406 \mu \mathrm{m}$ (400 $\mu \mathrm{m}$ in holotype). Preserved specimen colourless. Nauplius eye absent. Body composed of prosome [consisting of cephalothorax and three free pedigerous somites (first pedigerous fused to cephalothorax)], and urosome (consisting 

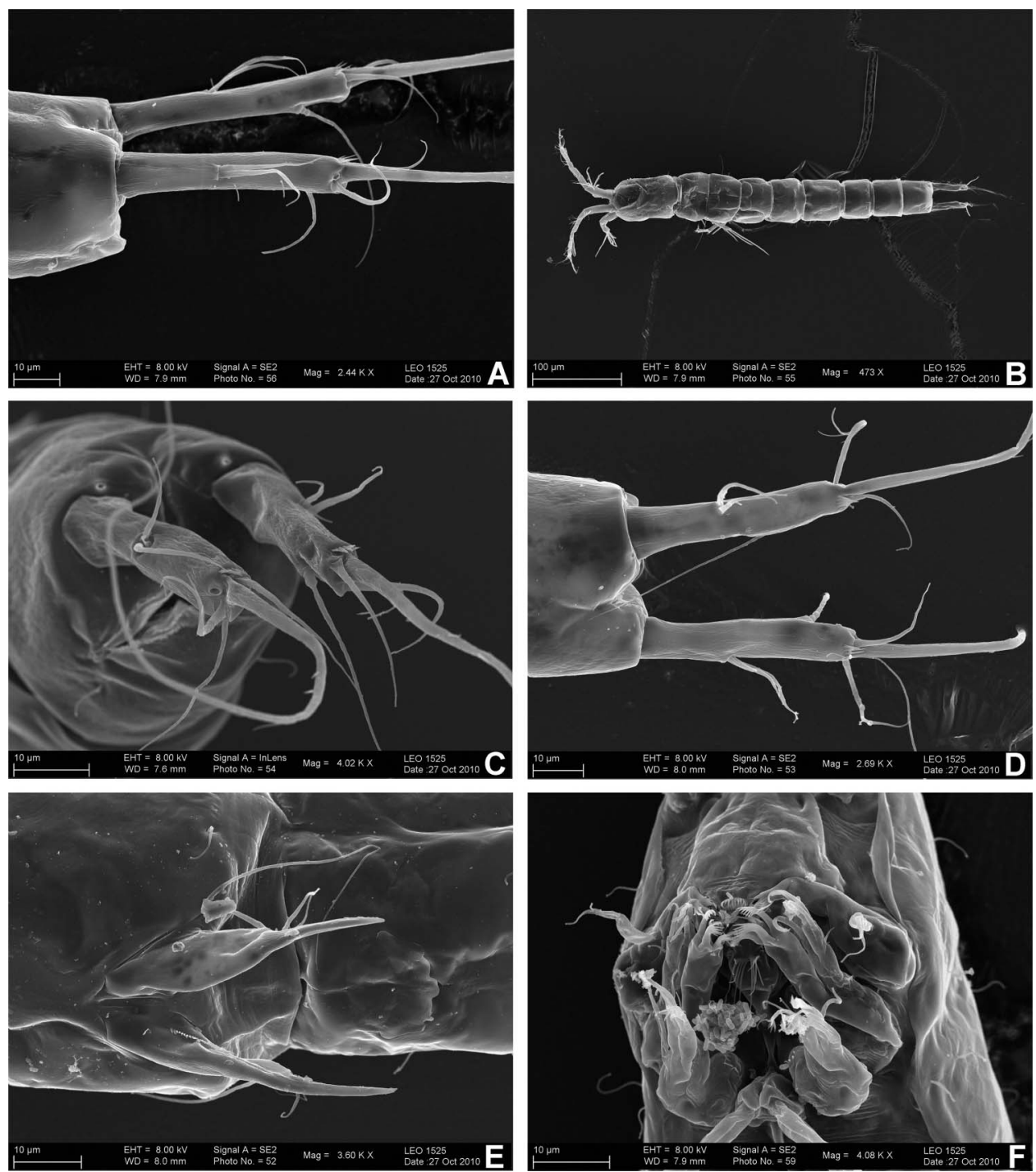

Figure 2. Proserpinicaris young sp. nov., scanning electron micrographs, (A) paratype male 2; (B) paratype female 1; (C) paratype female 2; (D-F) allotype female. (A) Anal somite and caudal rami, lateral view; (B) habitus, dorsal view; (C) anal somite and caudal rami, posterior view; (D) anal somite and caudal rami, ventral view; (E) fifth legs and genital area, ventral view; (F) mouth appendages, ventral view. Scale bars $100 \mu \mathrm{m}$ for (B), $10 \mu \mathrm{m}$ for all others.

of fifth pedigerous somite, genital somite, four abdominal somites, and caudal rami). Podoplean boundary between prosome and urosome inconspicuous. Habitus (Figures 1A, 3A) cylindrical and very slender, without any demarcation between prosome and urosome; prosome/urosome ratio about 0.9 in dorsal view; greatest width in dorsal view at fourth and fifth pedigerous somites, but hard to establish; free prosomal somites in lateral view narrower than cephalothorax or urosome. Body length/width 


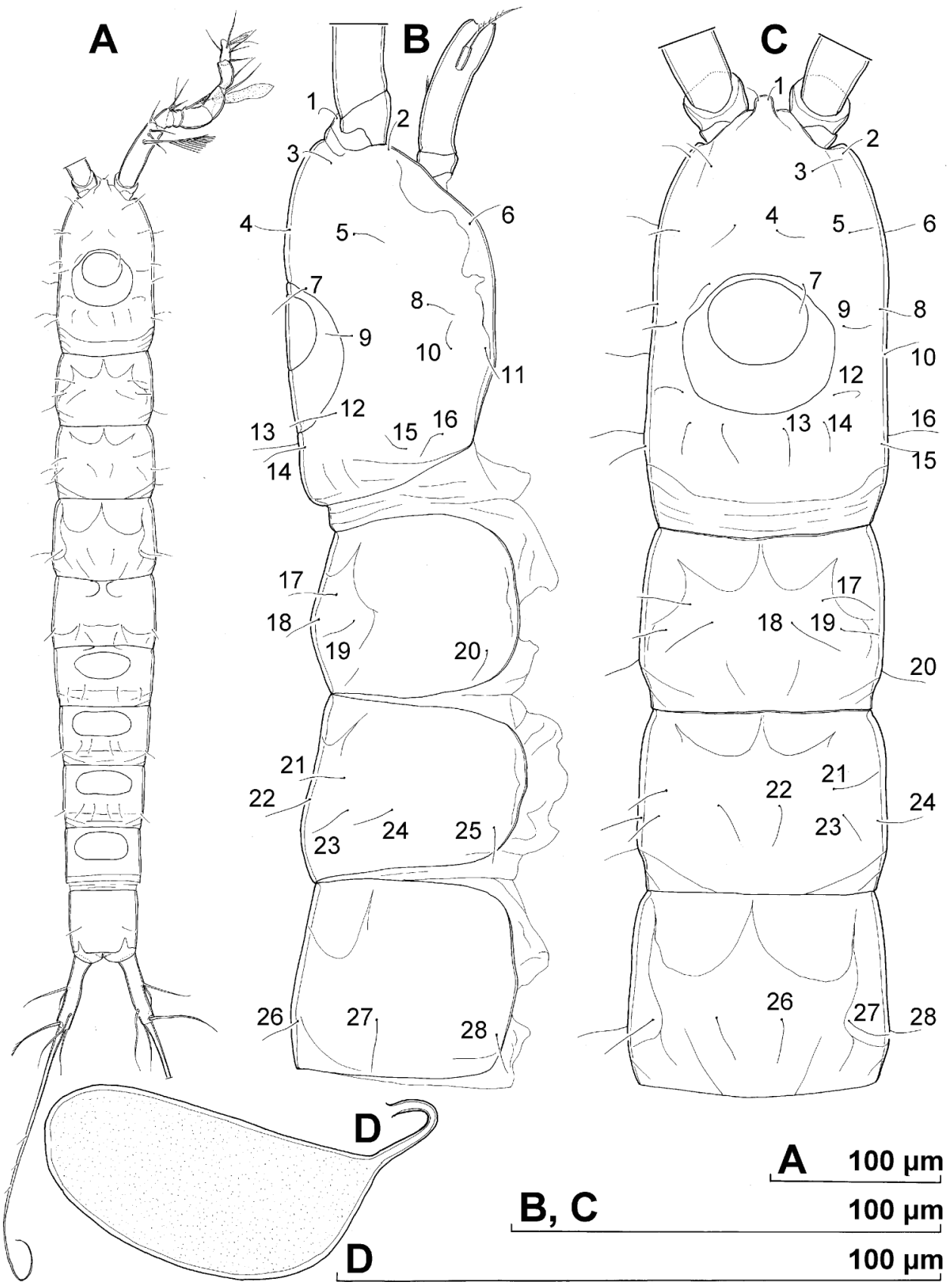

Figure 3. Proserpinicaris young sp. nov., line drawings, paratype male 3. (A) Habitus, dorsal view; (B) prosome with most appendages omitted, lateral view; (C) prosome, dorsal view; (D) spermatophore. Scale bars $100 \mu \mathrm{m}$ for all. Arabic numerals numbering sensilla consecutively from anterior to posterior end of body, and from dorsal to ventral side. 


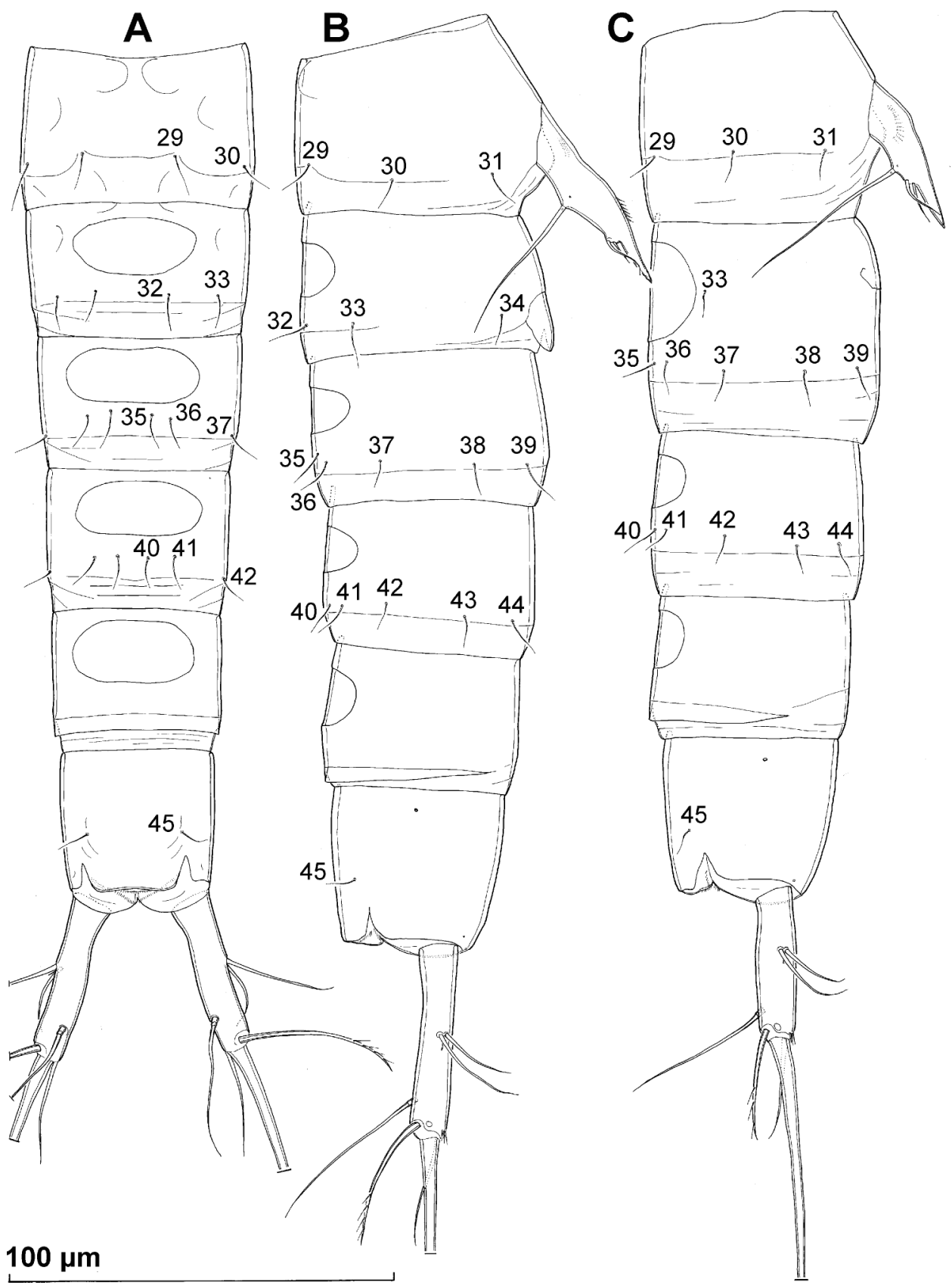

Figure 4. Proserpinicaris young sp. nov., line drawings, (A, B) paratype male 3; (C) paratype female 3. (A) Urosome, dorsal view; (B) urosome, lateral view; (C) urosome, lateral view. Scale bar $100 \mu \mathrm{m}$ for all. Arabic numerals numbering sensilla consecutively from anterior to posterior end of body, and from dorsal to ventral side. 


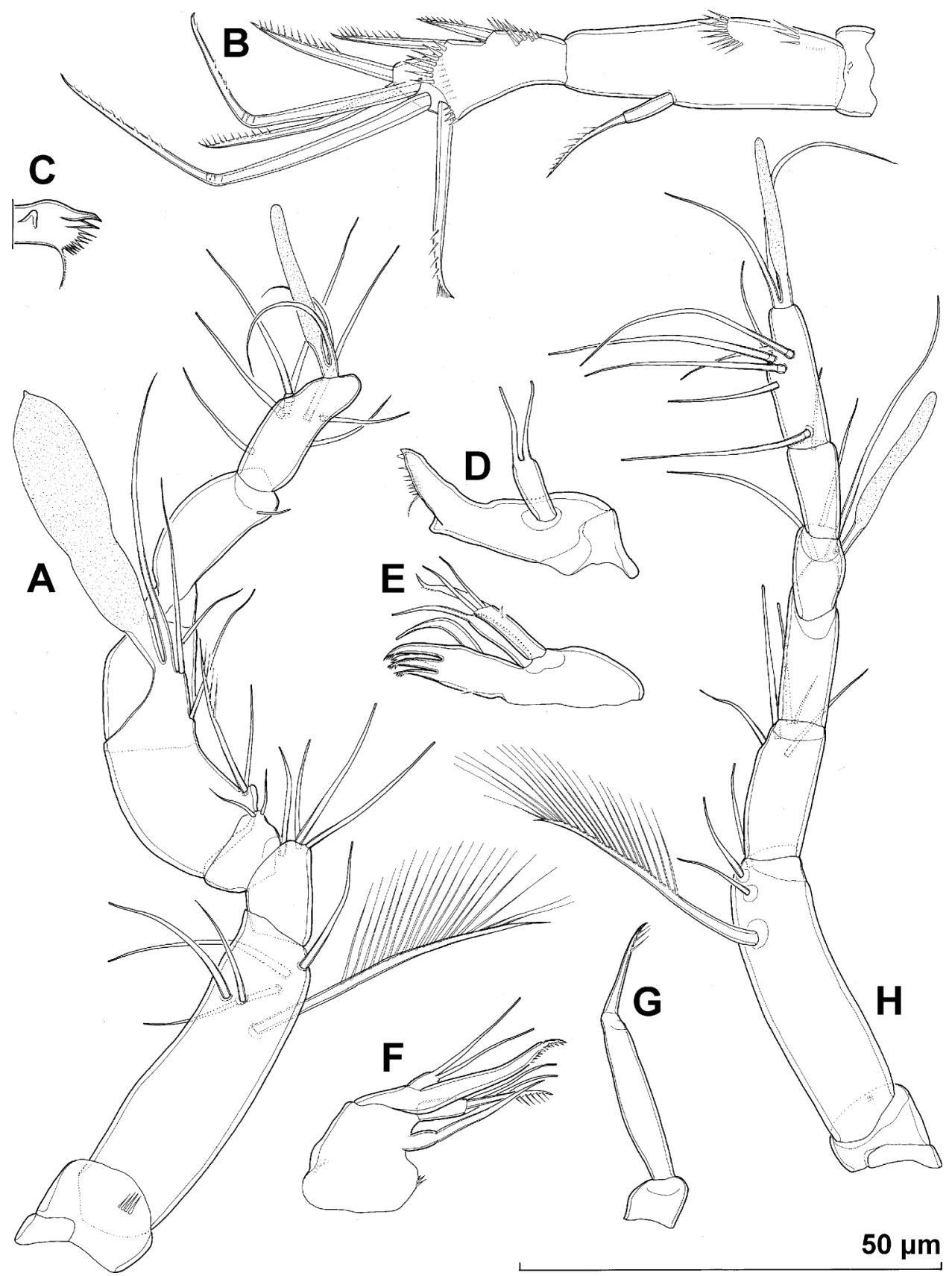

Figure 5. Proserpinicaris young sp. nov., line drawings, (A-G) paratype male 3; $(\mathrm{H})$ paratype female 3. (A) Antennula, ventral view; (B) antenna, latero-dorsal view; (C) cutting edge of mandibula, anterior view; (D) mandibula, postero-ventral view; (E) maxillula, posterior view; (F) maxilla, anterior view; (G) maxilliped, anterior view; (H) antennula, dorsal view. Scale bar $50 \mu \mathrm{m}$ for all. 


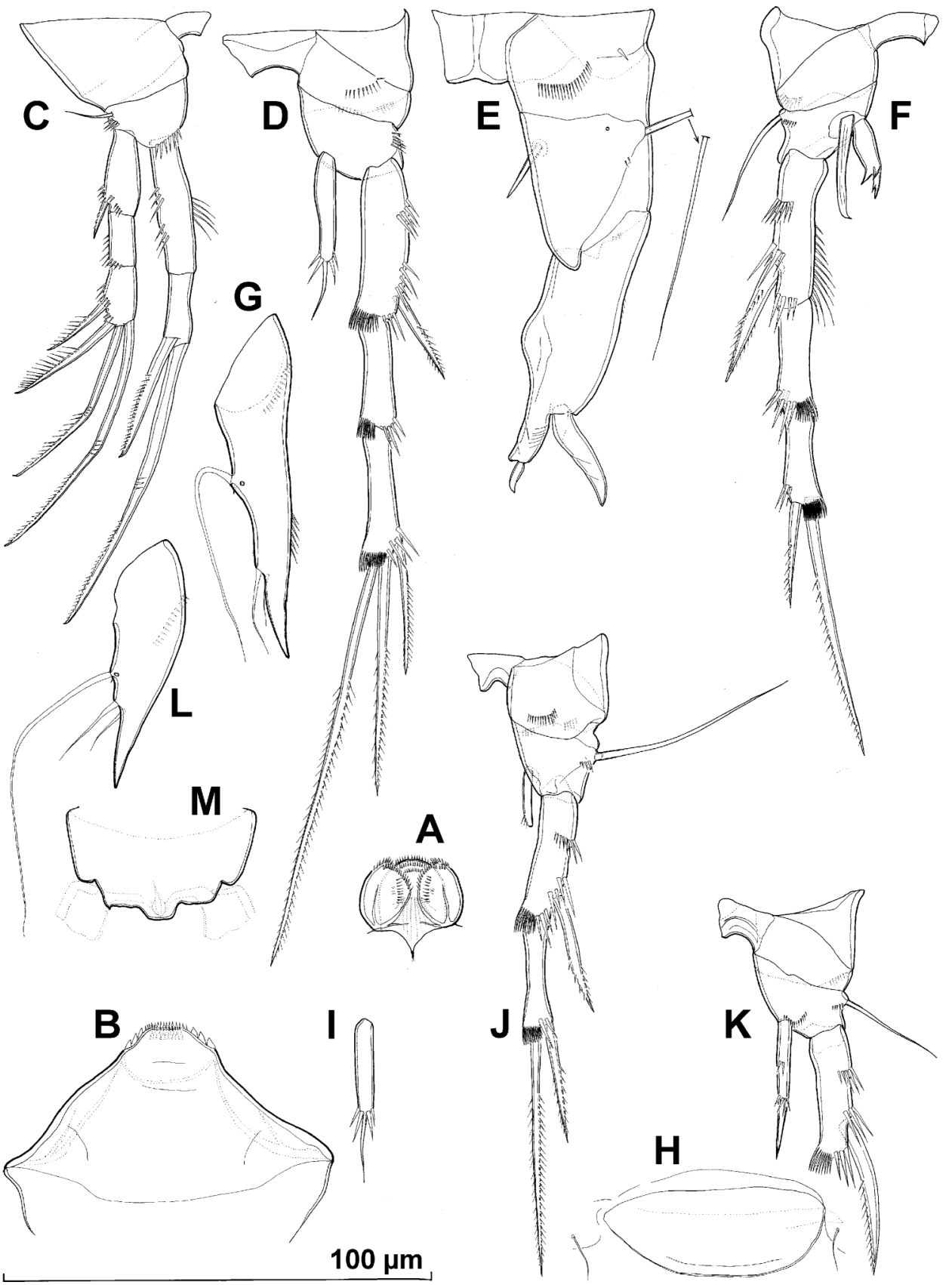

Figure 6. Proserpinicaris young sp. nov., line drawings, (A-H) paratype male 3; (I-M) paratype female 3. (A) Paragnaths, anterior view; (B) labrum, anterior view; (C) first swimming leg, anterior view; (D) second swimming leg, anterior view; (E) third swimming leg, anterior view; (F) fourth swimming leg, anterior view; (G) fifth leg, anterior view; H, sixth leg, anterior view; (I) endopod of second swimming leg, posterior view; (J) third swimming leg, anterior view; (K) fourth swimming leg without last two exopodal segments, anterior view; (L) fifth leg, anterior view; (M) fused sixth legs and genital field, ventral view. Scale bar $100 \mu \mathrm{m}$ for all. 
ratio 8.1; cephalothorax about as wide as genital somite. Free pedigerous somites without any lateral or dorsal expansions, all connected by well developed arthrodial membranes. Hyaline fringe of all somites smooth, very narrow and hard to distinguish from arthrodial membranes, especially dorsally, except in preanal somite, with hyaline fringe well developed dorsally and partly laterally, but not ventrally (Figures 1A, 3A, 4A,B). Integument weakly sclerotized, smooth, ornamented only with sensilla and pores (no spinules or cuticular pits), with round dorsal double cuticular window on cephalothorax, and oval dorsal simple cuticular windows on genital and three postgenital somites. Pleural areas of cephalothorax and free pedigerous somites not well developed, cephalic appendages and coxae of swimming legs clearly exposed in lateral view.

Rostrum (Figure 3C) small, membranous, not demarcated at base, ornamented with two large dorsal sensilla, linguiform, not reaching distal margin of first antennular segment, about as long as wide.

Cephalothorax (Figures 1A,E, 3A-C) about 1.8 times as long as wide in dorsal view; representing $21 \%$ of total body length. Surface of cephalic shield ornamented with 16 pairs of large sensilla (numbered from anterior to posterior and from dorsal to ventral side in Figure 3B,C); no small sensilla, cuticular pores, pits, or any other ornamentation; five pairs of sensilla surround double cuticular window, but its surface completely smooth; except for one pair of sensilla (no. 11) visible from dorsal view. Arthrodial membrane between cephalothorax and second pedigerous somite (first free) larger than between any other somites.

Second pedigerous somite (Figures 1A, 3A-C) as wide as posterior half of cephalothorax in dorsal view, with four pairs of large sensilla (three dorsal and one lateral; nos. 17-20), and with arched dorsal sutures in anterior half joining to make interesting crown-like pattern.

Third pedigerous somite (Figures $1 \mathrm{~A}, 3 \mathrm{~A}-\mathrm{C}$ ) slightly wider and longer than second, with five pairs of large sensilla (nos. 21-25), also with arched dorsal sutures making crown-like pattern, but less pronounced than in second pedigerous somite.

Fourth pedigerous somite (Figures $1 \mathrm{~A}, 3 \mathrm{~A}-\mathrm{C}$ ) widest prosomal somite in dorsal view, slightly longer than third, with only three pairs of large posterior sensilla (nos. 26-28), with deeper and longer arched sutures than in any other somite.

First urosomite (Figures 1A,D, 4A,B) about as wide as fourth pedigerous somite but slightly shorter, also with three pairs of large posterior sensilla (nos. 29-31), with two small arched dorsal sutures in anterior half, and with nearly continuous horizontal suture in posterior half at level of sensilla insertion.

Second urosomite (= genital somite) (Figures 1A,D, 4A,B) slightly narrower and shorter than first, with oval dorsal cuticular window in anterior half, also with three pairs of posterior sensilla (nos. 32-34), but two dorsal pairs (nos. 32 and 33) closer to each other than in first urosomite.

Third urosomite (Figures 1A, 4A,B) about as long as second but slightly narrower, with shorter and wider dorsal cuticular window, and with five pairs of large posterior sensilla (nos. 35-39); two dorsal pairs (nos. 32 and 33) much closer to each other than in second urosomite.

Fourth urosomite (Figures 1A, 4A,B) slightly narrower than third, but also with five pairs of large posterior sensilla (nos. 40-44), and with similar sized dorsal cuticular window. 
Fifth urosomite (= preanal somite) (Figures 1A, 4A,B) slightly narrower and longer than fourth, with largest dorsal cuticular window of all urosomites, and without any surface ornamentation.

Sixth urosomite (= anal somite) (Figures 1A, 2A,4A,B) about 1.2 times as long as and slightly narrower than preanal somite, ornamented with pair of large dorsal sensilla at base of anal operculum, pair of large lateral cuticular pores in anterior half, pair of ventral pores at base of caudal rami, and pair of minute ventro-lateral pores in posterior eighth of somite length (no spinules on ventral surface). Anal operculum well developed, unornamented on outer surface, with smooth and almost straight distal margin, not reaching posterior end of anal somite, representing $70 \%$ of somite's width. Anal sinus widely opened, ornamented with two long diagonal rows of slender spinules on ventral side, and two parallel rows on dorsal side (inner side of anal operculum).

Spermatophore (Figure 3D) about twice as long as wide, kidney-shaped, with narrow and curved neck. Note that spermatophore neck and its opening squeezed out and visible in upper right corner in Figure 1D.

Caudal rami (Figures 1A, 2A, 4A,B) very long and slender, about six times as long as greatest width (ventral view) and about 1.4 times as long as anal somite, cylindrical, parallel or slightly divergent, with space between them about twice that of one ramus width; armed with seven elements (three lateral, one dorsal and three apical). Ornamentation consists of large lateral cuticular pore near posterior margin, and posterior ventral row of several spinules along posterior margin. Dorsal seta slender and smooth, inserted closer to inner margin at about three-quarters of ramus length, about 0.8 times as long as caudal ramus, triarticulate (inserted on two small pseudojoints). Lateral setae slender and smooth, inserted very close to each other at two-fifths of ramus length, minute one between two larger ones and slightly posterior to them. Dorsal anterior lateral seta longest, half as long as ramus, 1.4 times as long as ventral anterior seta, and about nine times as long as minute seta. Inner apical seta smooth, inserted close to ventral margin, about 0.6 times as long as ramus. Middle apical seta strongest, without breaking plane, unipinnate, about 1.7 times as long as ramus, pointing distally, with slightly curled tip. Outer apical seta also without breaking plane and unipinnate, relatively strong basally but much shorter, about 0.8 times as long as ramus, inserted close to dorsal surface and pointing laterally.

Antennula (Figures 1E,F, 5A) slightly longer than cephalothorax, slender, eightsegmented, prehensile and strongly digeniculate, ornamented with four ventral spinules on first segment distally, and with ribbed elongated chitinous plate on anterior surface of sixth segment. First segment very short whereas second segment longest. Geniculation between third and fourth and between sixth and seventh segments; last two segments in line. Distal anterior corner of seventh segment produced into very small spiniform process, but larger proximal spiniform process present on fifth segment on anterior surface. Massive aesthetasc on fifth segment reaching beyond tip of appendage, fused basally to slightly shorter seta, with nipple distally; much shorter and more slender apical aesthetasc on seventh segment, fused basally to two setae (acrotheck). Armature formula: 0.6.4.2.6 + ae.1.1.9 + ae. All setae slender and all smooth, except largest seta on second segment and proximalmost seta on fifth segment; most setae with pore on tip; most proximal seta on second segment longest and strongest, unipinnate with extremely long spinules along anterior surface.

Antenna (Figures 1E, 5B) relatively stout and short, composed of coxa, allobasis, one-segmented endopod and one-segmented exopod. Coxa very short, unornamented. 
Allobasis about three times as long as wide, unarmed but ornamented with two rows of large spinules on anterior surface, and one short row of minute spinules on posterior surface. Endopod half as long as allobasis and twice as long as wide, with surface frill subdistally, ornamented with large spinules along anterior surface, armed laterally with two short spines (proximal one shorter) and apically with five strong elements (two geniculate). Exopod minute, cylindrical, about twice as long as wide, unornamented but armed with single apical seta, twice as long as segment. All antennal armature unipinnate.

Labrum (Figures 1A, 6B) large and triangular in lateral view, trapezoidal in anterior view, with narrow and straight cutting edge, without any ornamentation on anterior surface, with several parallel rows of spinules along cutting edge (three on outer distal corners strongest and very broad, leaf-like).

Paragnaths (Figures 1A, 6A) strongly fused into trilobate structure, with numerous distal rows of slender short spinules on lateral lobes, one distal row of minute spinules on central lobe, and another transverse row of 10 very long spinules on posterior surface of central lobe at about two-thirds of its length.

Mandibula (Figures 1A, 5C,D) with narrow cutting edge on elongated coxa, armed with one complex tooth ventrally, one unipinnate seta dorsally, and several smaller teeth and/or spinules in between. Palp one-segmented, cylindrical, about 2.5 times as long as wide, unornamented, and armed apically with two smooth and subequal setae, each with pore on tip.

Maxillula (Figures 1A, 5E) with relatively large praecoxa, arthrite rectangular, about 1.5 times as long as wide from lateral view, ornamented with single spinule on posterior surface near dorsal margin, armed with lateral strong seta and four apical elements (probably three spines and one strong seta; apical spines with crown of spinules on tip, resembling small hands). Coxal endite armed with one smooth seta apically. Basis slightly longer than coxal endite, armed with three apical setae (two smooth and slender, one curved and unipinnate), and single minute lateral seta. Endopod and exopod absent (fused to basis without trace), minute seta on basis probably representing remnants of exopodal armature. All coxal and basal setae, as well as smooth lateral seta on praecoxa, with pore on tip.

Maxilla (Figures 1A, 5F), composed of syncoxa, basis, and one-segmented endopod, ornamented with row of five spinules on inner side of syncoxa proximally, and with arched row of six spinules on posterior side of syncoxa close to outer margin. Syncoxa with two endites, basal armed with single smooth seta apically, distal armed with two smooth and one pinnate seta apically. Basis drawn out into strong and unipinnate claw, without seta at base, with cuticular pore on convex margin near distal tip. Endopod represented by minute segment, armed with two smooth subequal apical setae. All setae on maxilla with pore on tip.

Maxilliped (Figures 1A, 5G) with short and relatively strong syncoxa, unarmed and unornamented; basis slender, almost five times as long as wide and three times as long as syncoxa, unornamented and unarmed; endopod represented by short curved claw, swollen at base as indication of ancestral one-segmented endopod, ornamented with several strong spinules along concave margin distally, about 0.7 times as long as basis.

First swimming leg (Figures 1A, 6C) with smooth praecoxa, coxa and intercoxal sclerite. Praecoxa partly fused to coxa. Intercoxal sclerite very small, with narrow and concave distal margin. Basis somewhat shorter than coxa, pentagonal, ornamented 
with bunch of large spinules on outer margin, another bunch along distal margin at base of endopod, and armed with single short seta on outer margin. Exopod three-segmented, armed with one outer spine on first segment and four elements on third segment (two outer spines and two apical geniculate setae); ornamented with several large spinules along outer margin and distally on all segments. Endopod twosegmented, about as long as exopod; first segment reaching slightly beyond distal margin of second exopodal segment, about four times as long as wide, unarmed, ornamented with two short rows of large spinules on outer margin and one longer row of even longer spinules on inner margin; second segment armed apically with long geniculate seta and much shorter spine; endopodal geniculate seta 1.5 times as long as entire endopod, 1.2 times as long as larger geniculate exopodal seta, and almost 2.4 times as long as outer spine on endopod. All exopodal and endopodal armature unipinnate along outer margin.

Second swimming leg (Figures 1A, 6D) with smooth praecoxa, and intercoxal sclerite. Intercoxal sclerite large, trapezoidal, with deeply concave distal margin. Praecoxa triangular and large. Coxa short, rhomboidal, with diagonal row of small spinules on anterior surface and two shorter rows of minute spinules along distal margin on posterior surface. Basis larger than coxa, semicircular, unarmed, ornamented with row of spinules on outer margin. Exopod three-segmented, ornamented with large spinules along outer margin, and with distal hyaline frills on each segment on inner side; first segment armed with single outer spine; second segment unarmed; third segment armed with three long elements (probably outer spine and two apical setae), innermost one slightly longer than exopod; all exopodal armature bipinnate. Endopod one-segmented, cylindrical and slender, almost five times as long as wide, reaching three-quarters of first exopodal segment in length, ornamented with four large spinules along apical margin; armed apically with single smooth seta, about 0.6 times as long as segment and pointing inwards.

Third swimming leg (Figures 1B, 6E) with smooth intercoxal sclerite, larger than on other legs, trapezoidal, smooth, and with almost straight distal margin. Praecoxa not well defined on anterior surface, triangular on posterior surface, about as large as in second leg, unarmed, ornamented with single spinule on anterior surface. Coxa rectangular, with arched row of large spinules on anterior surface. Basis robust, ornamented with two minute spinules and one pore on anterior surface, several minute spinules along distal margin on posterior surface, armed with outer long and slender seta; distal inner corner of basis produced distally as short blunt chitinous beak, probably reinforcing exopod. Endopod represented by single smooth and strong armature element, inserted on inner margin at one-third of basis length. Exopod with both segments fused; ancestral proximal segment twice as long as wide, curved inwards and with inner chitinous bulge at two-thirds of its length, ornamented with several minute spinules along outer margin, and single small spinule on distal outer corner, armed subapically with simple, strong, smooth and inwardly curved spine, 1.6 times as long as apophysis; ancestral distal segment (apophysis) conical, oriented slightly inwards, unornamented, and armed with single short leaf-like seta on top with its tip pointing outwards.

Fourth swimming leg (Figures 1C, 6F) with smooth praecoxa and intercoxal sclerite. Intercoxal sclerite shorter and smaller than in second leg, with equally long and concave distal margin. Praexoca, large and triangular from anterior view. Coxa rhomboidal, slightly smaller than in second leg, unarmed, ornamented with short distal row 
of spinules on posterior surface. Basis also short and rhomboidal in anterior view, armed with single outer seta, ornamented with several spinules on outer margin and with huge chitinous spiniform process between exopod and endopod, pointing inwards and leaf-like distally. Exopod three-segmented, ornamented with few large spinules along outer margin on all segments, and with hyaline frills distally on inner side of second and third segments; first segment with straight inner margin, additionally ornamented with long row of long and slender spinules along inner margin, armed with single outer spine; second segment unarmed; third segment armed with outer spine and long and strong apical seta; apical seta 2.7 times as long as third exopodal segment, 0.8 times as long as entire exopod, and more than twice as long as outer spine. Endopod shorter than spiniform process on basis, one-segmented and spiniform, with apical crown of four large spinules, fused basally and arranged as small scoop pointing outwards. Apical endopodal scoop and tip of basal hyaline spine forming pincer-like structure.

Fifth leg (Figures 1D, 4B, 6G) simple elongated triangular plate, inner distal corner produced into very long and distally serrate spiniform process, ornamented with short row of six large spinules along inner margin, longer row of smaller spinules on posterior surface proximally, and cuticular pore on anterior surface, armed with three smooth setae; outermost seta (ancestral basal one) longest, almost as long as entire leg; middle seta (probably ancestral outer endopodal) much shorter than basal seta, hardly reaching tip of inner distal process, 0.2 times as long as leg, and 1.7 times as long as innermost seta (inner endopodal). Fifth legs distinct at base, with very small space between them, pointing caudally, and almost reaching distal margin of sixth legs with their tips.

Sixth legs (Figures 1D, 6H) smooth, unarmed and unornamented, forming simple operculum covering gonopore, probably both fused together, or right one reduced and left one enlarged.

Female (based on allotype and several paratypes). Body length, excluding caudal setae, from 375 to $400 \mu \mathrm{m}$ (385 $\mu \mathrm{m}$ in allotype). Habitus (Figure 2B), ornamentation of prosomites, colour and nauplius eye similar to male, except genital and first abdominal somite fused into double somite and habitus slightly less slender.

Genital double somite (Figures 2B,E, 4C) about as wide as long (dorsal view), without any trace of subdivision, with oval dorsal cuticular window in anterior half, much larger than that in male (originating from fused windows of two ancestral somites). Genital complex (Figures 2E, 6M) occupying anterior ventral half of genital double somite; genital apertures covered by vestigial sixth legs; median copulatory pores also covered by fused sixth legs; seminal receptacles small, hard to distinguish from internal tissue and gut content, rectangular; copulatory ducts weakly sclerotized. All posterior sensilla homologous to those on male third urosomite, while two sensilla from male second urosomite missing (nos. 32 and 34).

Third, fourth (preanal) and fifth (anal) urosomites very similar to male (Figures 2B-D, 4C).

Caudal rami (Figures 2B-D, 4C) slightly shorter in proportion to anal somite, about five times as long as wide in ventral (or dorsal) view, but also cylindrical and parallel or slightly divergent, with armature and ornamentation as in male.

Antennula (Figures 2B, 5H) seven-segmented, ornamented on first segment with few minute spinules on ventral surface, not geniculate, with slender aesthetasc on fourth segment, not reaching beyond tip of appendage, and more slender apical 
aesthetasc on seventh segment, fused basally to two apical setae; proximal aesthetasc much more slender than in male; setal formula: 0.4.5.2 + ae.1.0.9 + ae. All setae, except proximalmost one on second segment, smooth, and most seta with pore on tip.

Antenna (Figure 2B), labrum (Figure 2F), paragnaths (Figure 2F), mandibula (Figure 2F), maxillula (Figure 2F), maxilla (Figure 2F), maxilliped (Figure 2F), first swimming leg and second swimming leg (Figure 6I) similar to male.

Third swimming leg (Figure 6J) with smooth praecoxa and intercoxal sclerite. Coxa with arched row of large spinules on anterior surface, and two rows of spinules along distal margin on posterior surface, unarmed. Basis ornamented with several spinules on outer margin distally, armed with very long and smooth outer seta about as long as entire exopod. Exopod two-segmented, ornamented with large spinules along outer margin, both segments with hyaline frills distally on inner side; first segment armed with single outer spine; second segment with outer spine and apical strong seta; all elements bipinnate. Endopod one-segmented, small, linguiform, unarmed, reaching only two-fifths of first exopodal segment in length, ornamented with three small distal spinules.

Fourth swimming leg (Figure 6K) without spiniform process on basis. Endopod one-segmented, straight, ornamented with apical row of four spinules at base of apical spine and two spinules on inner margin; apical spine not distinct at base, smooth, and about 0.8 times as long as endopod; endopod with apical spine reaching posterior margin of first exopodal segment in length. Exopod similar to male, but inner margin of first exopodal segment lacks spinules.

Fifth leg (Figures 2E, 4C, 6L) also represented by simple cuticular plate, but without any spinules along inner margin and with longer row of minute spinules on posterior surface proximally. Armature as in male.

Sixth legs vestigial (Figures 2E, 6M), fused into simple cuticular flap, covering gonopores, unornamented and unarmed; distal margin thin, with produced lobe centrally and notches laterally.

\section{Distribution}

This species is only known from the type locality, Young River near Sanggu city in South Korea (Figure 12).

\section{Ecology}

Specimens were collected from the interstitial environment of the river bank sand, but no data are available on the water chemistry or sediment size.

Proserpinicaris wangpi sp. nov.

(Figures 7-9)

\section{Synonyms}

Parastenocaris nipponensis Chappuis: Miura, 1969: 253, figs 47-51. [partim.] Parastenocaris ondali sp. nov.: Lee and Chang, 2009: 170. [non] Parastenocaris nipponensis Chappuis: Chappuis, 1955: 187, figs 23-29; Chappuis, 1958: 429, fig. 12; Miura, 1964: 140, figs 45-54. 

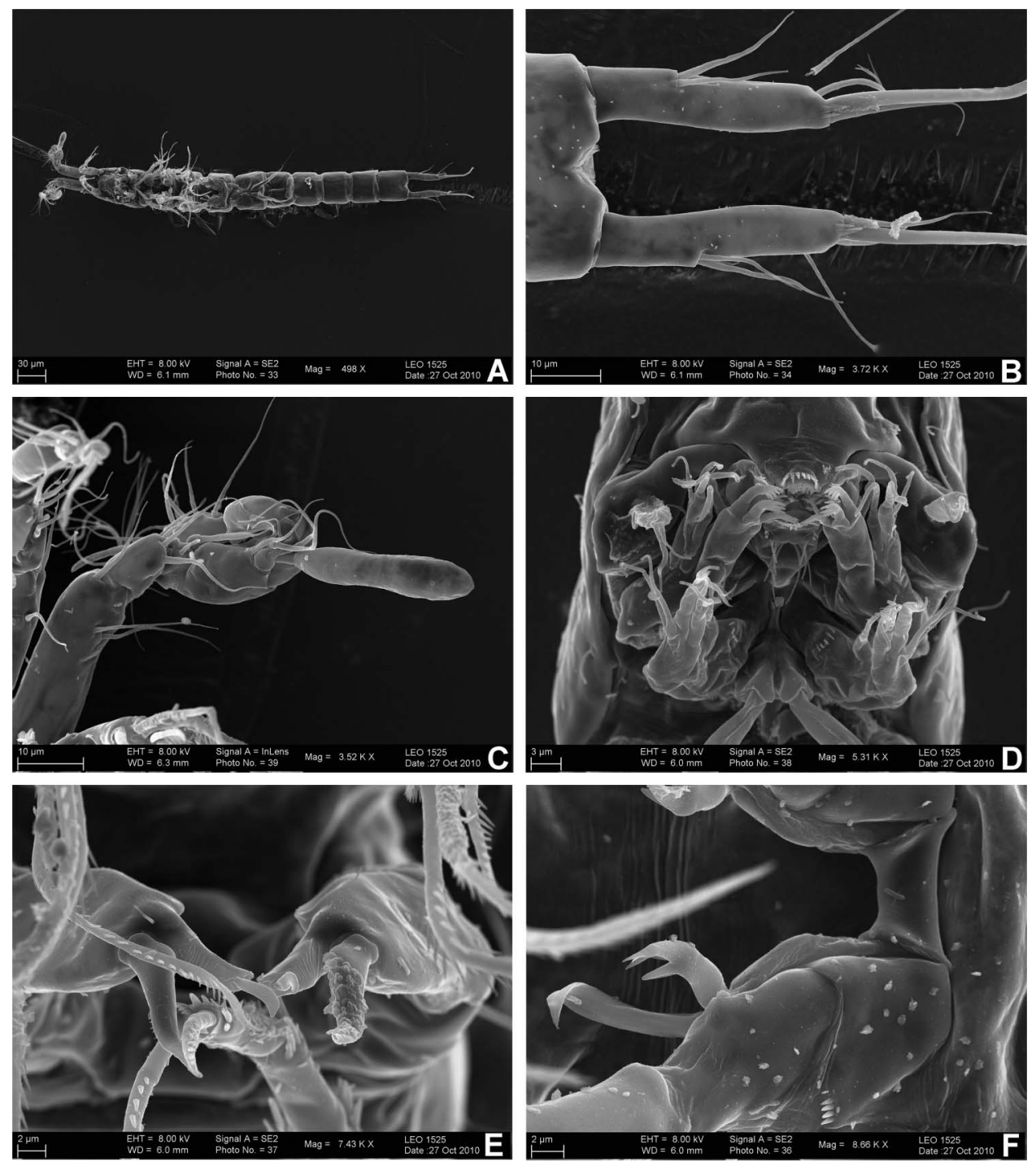

Figure 7. Proserpinicaris wangpi sp. nov., scanning electron micrographs, holotype male. (A) Habitus, ventral view; (B) anal somite and caudal rami, ventral view; (C) antennula ventromedial view; (D) mouth appendages, ventral view; (E) distal tips of third swimming legs and exopod of left fourth leg, ventral view; (F) coxa, intercoxal sclerite, basis, and endopod of fourth swimming leg, anterior view. Scale bars $30 \mu \mathrm{m}$ for (A), $10 \mu \mathrm{m}$ for (B, C), $3 \mu \mathrm{m}$ for (D), and $2 \mu \mathrm{m}$ for (E, F).

\section{Type locality}

South Korea, Gyungsangbuk-do region, Uljin city, Geunnam town, Wangpi stream, interstitial water from several beaches on banks, $36^{\circ} 57^{\prime} 41.4^{\prime \prime} \mathrm{N} 129^{\circ} 22^{\prime} 46.4^{\prime \prime} \mathrm{E}$.

\section{Specimens examined}

Types only: holotype male, allotype female, three paratypes (one male and three females) together on one scanning electron microscopy stub (collection number 



Figure 8. Proserpinicaris wangpi sp. nov., scanning electron micrographs, (A) holotype male; (B) paratype male; (C and D) allotype female. (A) Fifth pedigerous and genital somites, ventral view; (B) fifth legs, lateral view; (C) habitus, lateral view; (D) anal somite and caudal rami, lateral view. Scale bars $20 \mu \mathrm{m}$ for (C), $10 \mu \mathrm{m}$ for (A, D), $3 \mu \mathrm{m}$ for (B).

NIBRIV0000232619); four paratypes (one males and three females) dissected on one slide each (collection numbers NIBRIV0000232620 to 0000232623); additional three paratype females together in alcohol (NIBRIV0000232624); 12 paratypes from separate sample (two males, six females and four copepodids) together in alcohol (NIBRIV0000232625); all collected from type locality, 18 May 2010, leg. J.-L. Cho, all deposited in the National Institute of Biological Resources, South Korea.

\section{Etymology}

The species name refers to its type locality, Wangpi stream, and should be treated as a noun in apposition to the generic name.

\section{Description}

Male (based on holotype and several paratypes). Total body length from 355 to $373 \mu \mathrm{m}$ (360 $\mu \mathrm{m}$ in holotype). Colour, body segmentation, arthrodial membranes, and sensilla pattern as in P. young sp. nov. (see above). Habitus (Figure 7A) cylindrical and slender, without any demarcation between prosome and urosome; prosome/urosome ratio 0.7 ; greatest width hard to establish in dorsal view; free prosomites in lateral view narrower than cephalothorax and even slightly narrower than urosome. Body length/width ratio about 8.8; cephalothorax about as wide as genital somite. Free pedigerous somites 


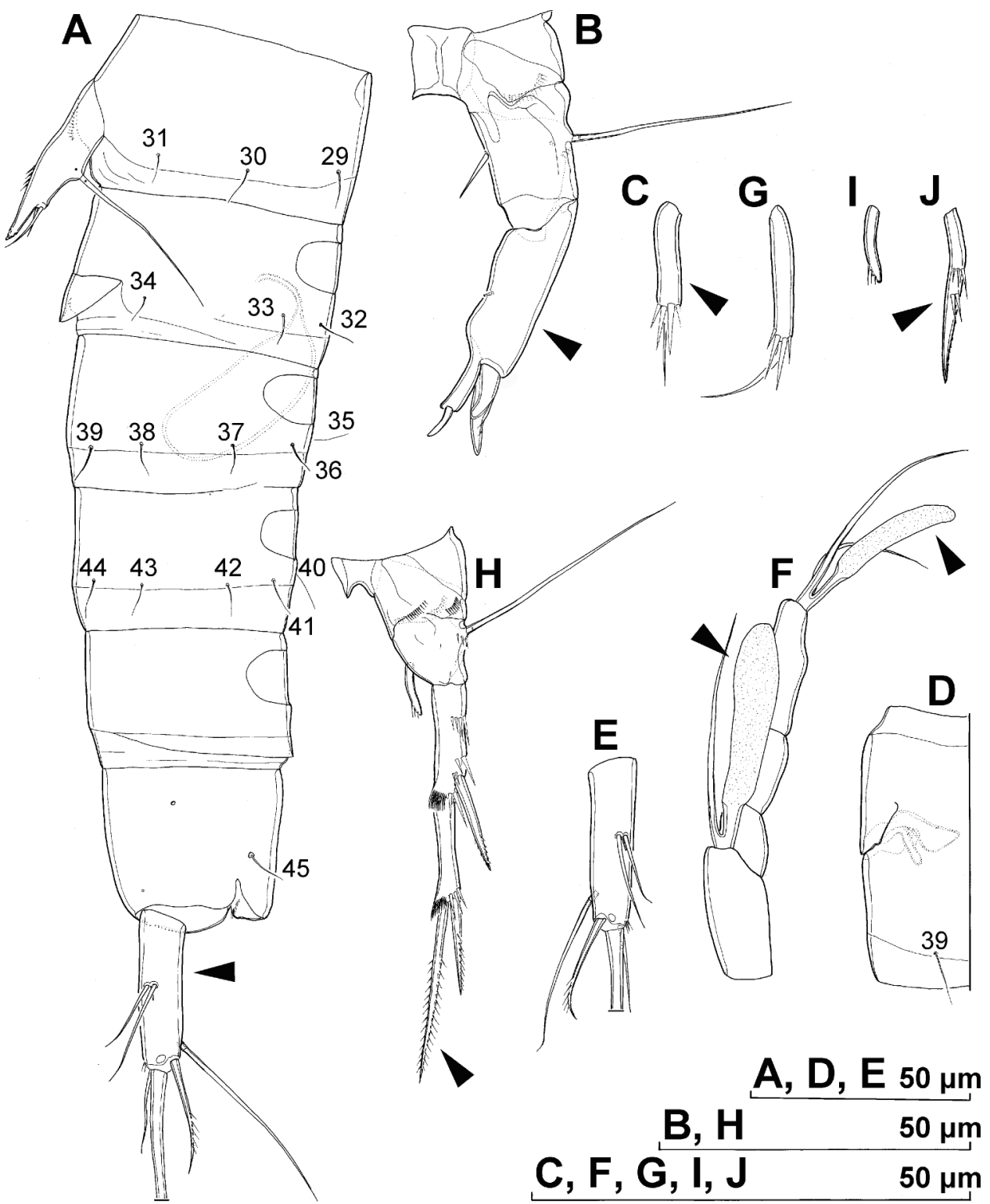

Figure 9. Proserpinicaris wangpi sp. nov., line drawings, (A-C) paratype male; (D-J) paratype female. (A) Urosome, lateral view; (B) third swimming leg, posterior view; (C) endopod of second swimming leg, anterior view; (D) ventral part of genital double-somite, lateral view; (E) right caudal ramus, lateral view; (F) last four antennal segments with incomplete armature, ventral view; $(\mathrm{G})$ endopod of second swimming leg, anterior view; $(\mathrm{H})$ third swimming leg, anterior view; (I) endopod of third swimming leg, anterior view; (J) endopod of fourth swimming leg, anterior view. Scale bars $50 \mu \mathrm{m}$ for all. Arrows indicate features different from previous species. 
without any expansions laterally or dorsally. Hyaline fringes of all somites smooth, very narrow and hard to distinguish from arthrodial membranes, except in preanal somite dorsally and partly laterally. Integument weakly sclerotized, very smooth, without any spinules or cuticular pits (except several spinules on caudal rami), ornamentated with 45 pairs of sensilla and four pairs of pores (three on anal somite, and one on caudal rami), dorsally with round cuticular window on cephalothorax and oval cuticular windows on genital and three postgenital somites, all in same position and of similar size to those in P. young. Pleural areas of cephalothorax (Figure 7D) and free pedigerous somites (Figure 7A) not well developed, cephalic appendages and coxae of swimming legs clearly exposed in lateral view; rostrum and cuticular sutures of free pedigerous posomites as in $P$. young.

Cephalothorax (Figure 7A,D) about 1.5 times as long as wide in dorsal view; representing $17 \%$ of total body length.

Urosomites (Figures 7A, 8A,B, 9A) proportionately shorter and wider than in P. young, but without any other difference. Anal somite also about 1.2 times as long as preanal somite.

Spermatophore (Figure 9A) proportionately smaller and slenderer than in P. young.

Caudal rami (Figures 7B, 9A) much shorter than in $P$. young (arrowed in Figure 9A), about 4.3 times as long as greatest width (ventral view) and about 1.2 times as long as anal somite, cylindrical, parallel, with space between them about 1.5 times one ramus' width; armed with seven armature elements (three lateral, one dorsal and three apical). Ornamentation consists of large lateral cuticular pore near posterior margin, and posterior ventral row of three large spinules. Dorsal seta slender and smooth, inserted closer to inner margin of ramus at about five-sixths of its length, 1.3 times as long as caudal ramus, triarticulate. Lateral setae slender and smooth, inserted very close to each other at two-fifths of ramus length, minute one between two larger ones and slightly posterior to them. Anterior lateral seta inserted more dorsally, longest, 0.7 times as long as ramus, 1.4 times as long as other anterior seta, and about seven times as long as minute seta. Inner apical seta smooth, inserted close to ventral margin, about 0.6 times as long as ramus. Middle apical seta strongest, without breaking plane, unipinnate, about 1.5 times as long as ramus, pointing distally, with slightly curled tip. Outer apical seta also without breaking plane and unipinnate, relatively strong basally but much shorter, about 0.7 times as long as ramus, inserted close to dorsal surface and pointing laterally.

Antennula (Figure 7C) relatively large, eight-segmented, prehensile and digeniculate, with distal part much more strongly clasped (probably random post-mortem effect) and fifth segment more robust than in $P$. young, but armature and ornamentation without any difference, except aesthetasc on fifth segment wider and slightly longer.

Antenna, labrum (Figure 7D), mandibula (Figure 7D), maxillula (Figure 7D), maxilla (Figure 7D), maxilliped (Figure 7D), and first swimming leg as in P. young.

Paragnaths (Figure 7D) with eight large spinules in transverse row on posterior surface of central lobe.

Second swimming leg (Figure 9C) as in P. young, except endopod only about four times as long as wide (arrowed in Figure 9C) and reaching three-fifths of first exopodal segment; apical seta 0.7 times as long as segment and pointing distally. 
Third swimming leg (Figures 7E, 9B) with narrower basis and proximal exopodal segment (arrowed in Figure 9B) than in P. young, and with shorter outer spine on proximal exopodal segment. Proximal exopodal segment 2.7 times as long as wide, with small tubular pore on posterior surface near inner margin (latter not observed in $P$. young). Distal outer corner of proximal exopodal segment smooth (spinule missing). Leaf-like seta on apophysis more curved than in $P$. young.

Fourth swimming leg (Figure 7F) as in P. young, except apical seta on third exopodal segment somewhat shorter (about 2.2 times as long as third exopodal segment and 0.6 times as long as entire exopod); endopod and large basal spiniform process exactly as those in $P$. young.

Fifth leg (Figure 8A,B) represented by simple triangular cuticular plate, inner distal corner produced into distally serrate spiniform process (shorter than in $P$. young), ornamented with four large spinules on inner margin, one arched proximal row of 14 minute spinules on posterior surface, and large cuticular pore on anterior surface; armature as in $P$. young.

Sixth legs (Figure 8A) smooth, unarmed and unornamented, forming simple operculum covering gonopore, slightly smaller than in $P$. young.

Female (based on allotype and several paratypes). Body length from 330 to $355 \mu \mathrm{m}$ (335 $\mu \mathrm{m}$ in allotype). Habitus (Figure 8C), ornamentation of prosomites, colour and nauplius eye similar to male; genital and first abdominal somite fused into double somite and habitus less slender; free prosomites significantly narrower than urosomites in lateral view.

Genital double somite (Figures 8C, 9D) about as wide as long (dorsal view), without any trace of subdivision, with oval dorsal cuticular window in anterior half, much larger than that in male (originating from fused windows of two ancestral somites). Genital complex occupying anterior ventral half of genital double somite; genital apertures covered by vestigial sixth legs; median copulatory pores also covered by fused sixth legs; seminal receptacles small, trapezoidal in lateral view, hard to distinguish from internal tissue and gut content; copulatory duct very short and weakly sclerotized. All posterior sensilla homologous to those on male third urosomite, whereas two sensilla from male second urosomite missing (nos. 32 and 34).

Third (Figure 8C), fourth (preanal) (Figure 8C), and fifth (anal) (Figure 8D) urosomites similar to male.

Caudal rami (Figures 8D, 9E) slightly shorter in proportion to anal somite, from 3.6 to 3.9 times as long as wide, but also cylindrical and parallel, with armature and ornamentation as in male.

Antennula (Figures 8C, 9F) segmentation, ornamentation and armature as in P. young, except both aaesthetascs much more robust (arrowed in Figure 9F).

Antenna, labrum, paragnaths, mandibula, maxillula, maxilla, maxilliped, first swimming leg, second swimming leg, exopod of fourth swimming leg similar to male.

Third swimming leg (Figures $8 \mathrm{C}, 9 \mathrm{H}$ ) as in P. young, but with shorter apical element on second exopodal segment (arrowed in Figure 9H).

Fourth swimming leg (Figures 8C, 9J) without spiniform process on basis. Endopod one-segmented, slightly curved, ornamented with apical row of two spinules at base of apical spine and three spinules on inner margin; apical spine not distinct at base, finely serrated (or bipinnate) distally, and about as long as endopod (i.e. proportionately longer than in P. young; arrowed in Figure 9J).

Fifth (Figure 8C) and sixth legs as in P. young. 


\section{Distribution}

In addition to the type locality, Wangpi stream near Uljin city in South Korea (Figure 12), this species probably lives in a well near Seongryu-gul cave at Uljin (less than $15 \mathrm{~km}$ away). Miura (1969) reported the latter population as Parastenocaris niponnensis Chappuis, 1955, and Lee and Chang (2009) synonymized Miura's record with their new species $P$. ondali Lee and Chang, 2009, presuming a wide distribution of $P$. ondali in Korea. In the light of the presently discovered short range endemism in this group, both were probably wrong. Most morphological characters reported by Miura (1969) agree with Proserpinicaris wangpi sp. nov., and the proximity of the two locations suggests that these two populations are most probably conspecific. Hence, we think Miura's record is likely to be synonymous with $P$. wangpi. Of course, the Japanese population of $P$. niponnensis is a distinct species.

\section{Ecology}

Specimens were obtained from several interstitial samples as well as from a well near a cave, which probably means that this species explores a wide range of subterranean habitats.

\section{Proserpinicaris imjin sp. nov.}

(Figures 10, 11)

\section{Type locality}

South Korea, Gyeonggido region, Paju city, Jeokseong town, Imjin river, interstitial water from sandy beaches, $37^{\circ} 59^{\prime} 04.4^{\prime \prime} \mathrm{N}, 126^{\circ} 55^{\prime} 41.2^{\prime \prime} \mathrm{E}$.

\section{Specimens examined}

Types only: holotype male and allotype female together on one scanning electron microscopy stub (collection number NIBRIV0000232626); one paratype male in alcohol (NIBRIV0000232627); four paratypes from a different sample (two males and two females) dissected on one slide each (collection numbers NIBRIV0000232628 to 0000232631); six paratypes from a different sample (four males and two females) together in alcohol (NIBRIV0000232632); all collected from the type locality, 14 July 2010, leg. J.L. Cho, all deposited in the National Institute of Biological Resources, South Korea.

\section{Etymology}

The species name refers to its type locality, Imjin river, and should be treated as a noun in apposition to the generic name.

\section{Description}

Male (based on holotype and several paratypes). Total body length from 342 to $350 \mu \mathrm{m}$ (342 $\mu \mathrm{m}$ in holotype). Colour, body segmentation, arthrodial membranes and sensilla pattern as in P. young sp. nov. (see above). Habitus (Figure 10A) cylindrical but not very slender, without any demarcation between prosome and urosome; 

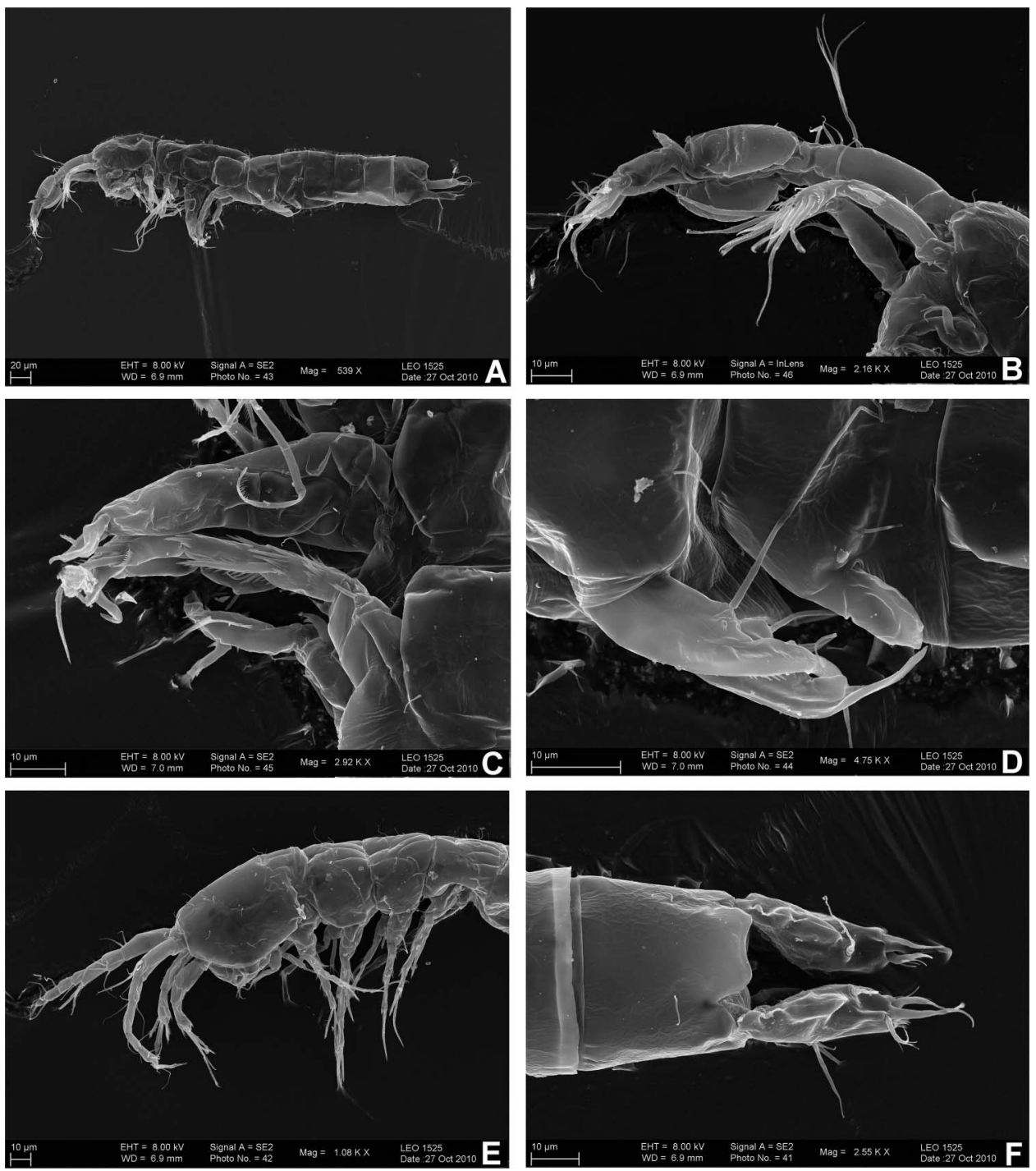

Figure 10. Proserpinicaris imjin sp. nov., scanning electron micrographs, (A-D) holotype male; (E and F) allotype female. (A) Habitus, lateral view; (B) antennulae and antennae, lateral view; (C) third and fourth swimming legs, lateral view; (D) fifth and sixth legs, lateral view; (E) prosome, lateral view; (F) anal somite and caudal rami, dorsal view. Scale bars $20 \mu \mathrm{m}$ for (A), $10 \mu \mathrm{m}$ for all others.

prosome/urosome ratio 0.7; greatest width in dorsal view hard to establish. Body length/width ratio only about 7.2; cephalothorax about as wide as genital somite; free prosomites in lateral view about as wide as cephalothorax and not narrower than urosome, without any expansions laterally or dorsally. Hyaline fringe of all somites smooth, very narrow and hard to distinguish from arthrodial membranes, except in preanal somite dorsally and partly laterally. Integument very weakly sclerotized, much 


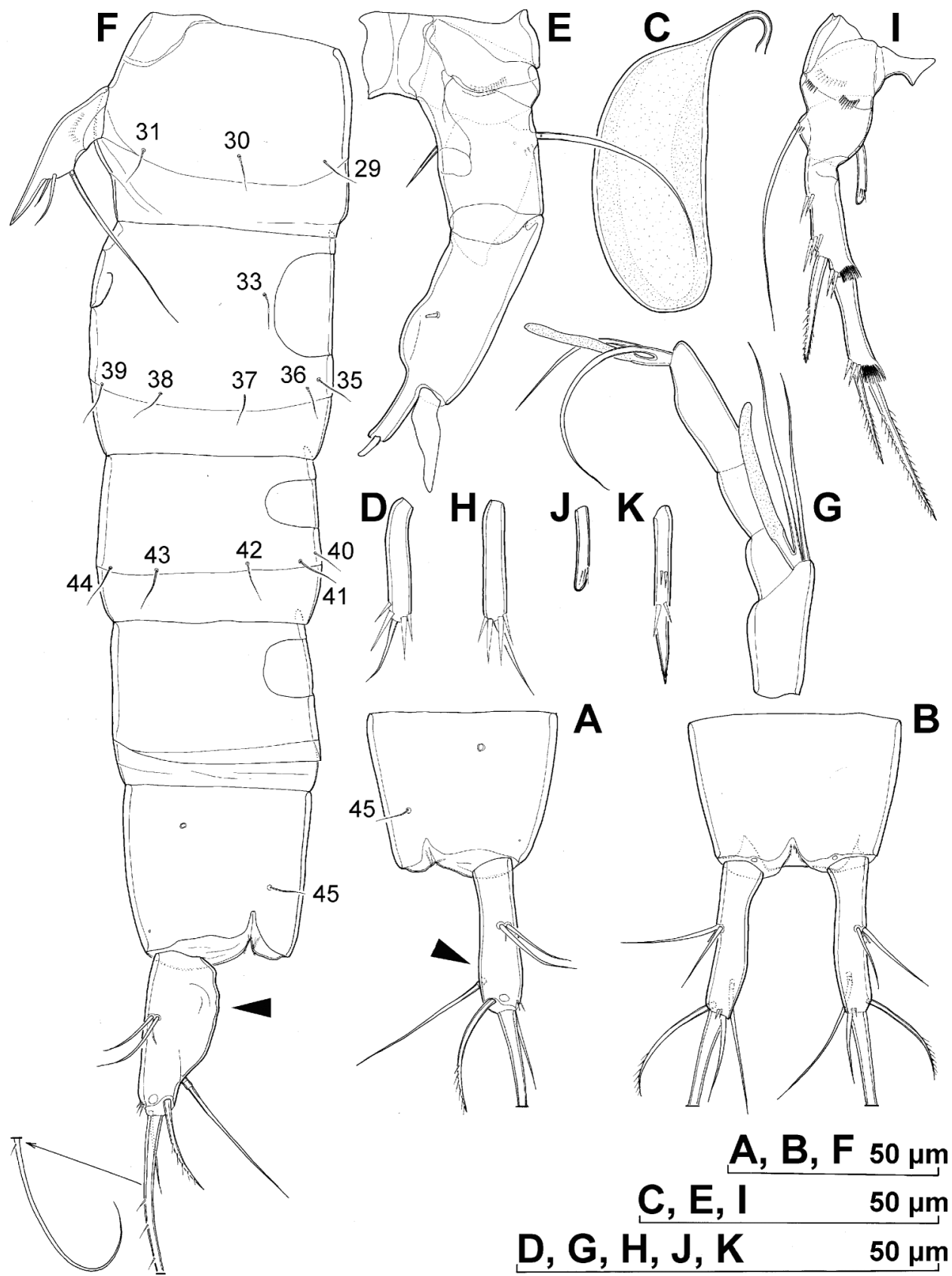

Figure 11. Proserpinicaris imjin sp. nov., line drawings, (A-E) paratype male; (F-K) paratype female. (A) Anal somite and right caudal ramus, lateral view; (B) anal somite and caudal rami, ventral view; (C) spermatophore; (D) endopod of second swimming leg, anterior view; (E) third swimming leg, posterior view; (F) urosome, lateral view; (G) last four antennular segments with incomplete armature, ventral view; $(\mathrm{H})$ endopod of second swimming leg, anterior view; (I) third swimming leg, anterior view; $(\mathrm{J})$ endopod of third swimming leg, anterior view; $(\mathrm{K})$ endopod of fourth swimming leg, anterior view. Scale bars $50 \mu \mathrm{m}$ for all. Arrows indicate features different from previous two species. 
softer than in $P$. young or in $P$. wangpi sp. nov., without any spinules or cuticular pits (except several spinules on caudal rami), but with slightly wrinkled surface, ornamentated as in $P$. young and $P$. wangpi with 45 pairs of sensilla and four pairs pores (three on anal somite, and one on caudal rami), dorsally with round cuticular window on cephalothorax and oval cuticular windows on genital and three postgenital somites, all in same position and of similar size to those in $P$. young but not as well defined because of thin integument. Pleural areas of cephalothorax (Figure 10A,B) and free pedigerous somites (Figure 10C,D) not well developed, cephalic appendages and coxae of swimming legs clearly exposed in lateral view; rostrum and cuticular sutures of free pedigerous prosomites as in $P$. young.

Cephalothorax (Figure 10A,B) about 1.5 times as long as wide in dorsal view; representing $18 \%$ of total body length.

Urosomites (Figure 10A) proportionately shorter and wider than in $P$. young or even $P$. wangpi, but without any difference in ornamentation. Anal somite (Figures 10A, 11A,B) about as long as preanal somite, i.e. proportionately shorter than in $P$. young and $P$. wangpi; anal operculum clearly concave in dorsal view.

Spermatophore (Figure 11C) more slender than in P. young, about 2.4 times as long as wide.

Caudal rami (Figures 10A, 11A,B) from 3.2 to 3.6 times as long as greatest width and only about as long as anal somite, cylindrical in anterior part but slightly inflated in posterior part in lateral view (arrowed in Figure 11A), nearly parallel, with space between them about 1.5 times one ramus width; armed with seven armature elements (three lateral, one dorsal and three apical). Ornamentation consists of large lateral cuticular pore near posterior margin, and posterior ventral row of two small spinules. Dorsal seta slender and smooth, inserted closer to inner margin at about fourfifths, about as long as caudal ramus, triarticulate . Lateral setae slender and smooth, inserted very close to each other at two-fifths of ramus length, minute one between two larger ones and slightly posterior to them. Anterior lateral seta inserted more dorsally, longest, 0.6 times as long as ramus, 1.3 times as long as other anterior seta, and about seven times as long as minute seta. Inner apical seta smooth, inserted close to ventral margin, about 0.6 times as long as ramus. Middle apical seta strongest, without breaking plane, unipinnate, about 1.5 times as long as ramus, pointing distally, with slightly curled tip. Outer apical seta also without breaking plane and unipinnate, relatively strong basally but much shorter, about 0.8 times as long as ramus, inserted close to dorsal surface and pointing laterally.

Antennula (Figure 10B) relatively large, seven-segmented, prehensile and digeniculate, with distal part not clasped (probably random post-mortem effect), fifth segment more robust than in $P$. young, armature and ornamentation without any difference, except aesthetasc on fifth segment narrower and slightly shorter.

Antenna (Figure 10B) more slender than in P. young and P. wangpi, with allobasis slightly more than four times as long as wide. Armature and ornamentation as in P. young.

Labrum (Figure 10B), paragnaths (10A), mandibula (Figure 10B), maxillula (Figure 10A), maxilla (Figure 10A), maxilliped (Figure 10A) and first swimming leg (Figure 10A) as in $P$. young.

Second swimming leg (Figures 10A, 11D) as in P. young, except endopod not inflated in proximal half and about five times as long as wide and reaching three-fifths of first exopodal segment; apical seta 0.5 times as long as segment and pointing distally. 
Third swimming leg (Figures 10C, 11E) with tubular pore on posterior surface of first exopodal segment as in $P$. wangpi but general shape much more similar to that in $P$. young, except outer spine on first exopodal segment less robust and distal outer corner of proximal exopodal segment smooth (spinule missing). Leaf-like seta on apophysis smaller than in $P$. young and $P$. wangpi.

Fourth swimming leg (Figure 10C) as in P. young, except apical seta on third exopodal segment somewhat shorter (about twice as long as third exopodal segment and 0.6 times as long as entire exopod); endopod and large basal spiniform process as in P. young, except also slightly short in proportion to first exopodal segment.

Fifth leg (Figure 10D) simple triangular cuticular plate, inner distal corner produced into distally serrate spiniform process (longer than in $P$. young), ornamented with four to six large spinules on inner margin, one arched proximal row of 14 minute spinules on posterior surface, and large cuticular pore on anterior surface; armature as in $P$. young, except inner endopodal seta only half as long as outer endopodal seta, and not reaching tip of distal spiniform process .

Sixth legs (Figure 10D) smooth, unarmed and unornamented, forming simple operculum covering gonopore, slightly smaller than in $P$. young.

Female (based on allotype and several paratypes). Body length from 345 to $349 \mu \mathrm{m}$ (345 $\mu \mathrm{m}$ in allotype). Habitus (Figure 10E), ornamentation of prosomites, colour and nauplius eye similar to male; genital and first abdominal somite fused into double somite and habitus less slender; free prosomites slightly narrower than urosomites in lateral view.

Genital double somite (Figure 11F) slightly wider than long in dorsal view, without any trace of subdivision, with oval dorsal cuticular window in anterior half, much larger than that in male (originating from fused windows of two ancestral somites). Genital complex occupying anterior ventral half of genital double somite; genital apertures covered by vestigial sixth legs; median copulatory pores also covered by fused sixth legs; seminal receptacles small, hard to distinguish from internal tissue and gut content; copulatory duct very short and weakly sclerotized. All posterior sensilla homologous to those on male third urosomite, while two sensilla from male second urosomite missing (nos. 32 and 34).

Third (Figure 11F), fourth (preanal) (Figure 11F) and fifth (anal) (Figures 10F, $11 \mathrm{~F})$ urosomites similar to male.

Caudal rami (Figures 10F, 11F) laterally compressed but inflated in lateral view (arrowed in Figure 11F), shorter in proportion to anal somite than in male, only about twice as long as wide. Apical armature in allotype much reduced in length, all less than half as long as caudal rami, but in paratypes not much different to those in male (except outer apical seta slightly shorter). Lateral armature and ornamentation as in male.

Antennula (Figures 10E, 11G) segmentation, ornamentation and armature as in P. young, with both aesthetascs very slender (i.e. much more slender than in $P$. wangpi).

Antenna (Figure 10E), mandibula (Figure 10E), maxillula (Figure 10E), maxilla (Figure 10E), maxilliped (Figure 10E), first swimming leg (Figure 10E), second swimming leg (Figures 10E, 11H), and exopod of fourth swimming leg (Figure 10E) similar to male.

Third swimming leg (Figure 11I,J) as in P. young, but with shorter apical element (even shorter than in $P$. wangpi) on second exopodal segment. 
Fourth swimming leg (Figures 10E, 11K) without spiniform process on basis. Endopod one-segmented, straight, ornamented with apical row of two spinules at base of apical spine and three spinules on inner margin; apical spine not distinct at base, finely serrated (or bipinnate) distally, and about 0.8 times as long as endopod.

Fifth leg (Figure 11F) also simple cuticular plate, but without any spinules along inner margin and with shorter distal spiniform process. Armature similar to male.

Sixth legs (Figure 11F) vestigial, simple cuticular plates, covering gonopores, unornamented and unarmed, completely fused, forming simple flap.

\section{Distribution}

This species is only known from the type locality, Imjin river near Jeokseong town in South Korea (Figure 12).

\section{Ecology}

Specimens were obtained from interstitial habitats on the river banks, but no data are available on the water chemistry or sediment size.

\section{Discussion}

Proserpinicaris young sp. nov., $P$. imjin sp. nov. and $P$. wangpi sp. nov. are all closely related to each other, as well as to another Korean congener, $P$. ondali (Lee and Chang, 2009) comb. nov., described from Ondal-gul Cave near Danyang (Lee and Chang 2009; Chang 2010; see Figure 12). Their morphological differences are mostly related to the shape of the caudal rami, general habitus appearance, details in the shape of the fifth leg, as well as some other details in ornamentation of somites and armature of antennulae, but these differences are not smaller than those between some European members of this genus, especially those from Italy and its islands, France, and Spain (see Chappuis,1937; Cottarelli et al. 1980; Bruno and Cottarelli 1998; Pesce et al. 1988; Cottarelli 1989; Rouch 1990, 1992, 1996; Martínez Arbizu 1997). The easiest way to distinguish these Korean species is by the shape of their caudal rami. They are shortest in $P$. imjin (see Figure 10A,F), and even inflated in lateral view in females, resembling those of $P$. phyllura (Kiefer, 1938) comb. nov., and some Italian populations of P. proserpina (Chappuis, 1938), although the latter may be a sign of undescribed distinct species. The hypothesis of Schminke (1991) about the caudal rami shape being a polymorphic character in parastenocaridids was never challenged nor tested using molecular methods. Some recent molecular studies (Karanovic and Cooper 2011a,b) show that the caudal rami shape is relatively constant within all Australian parastenocaridid species, despite being a major morphological difference between some closely related congeners. Proserpinicaris imjin also has a less vermiform habitus than any other Korean species, but its inner distal process on the male fifth leg is much longer and more robust than in the other three species, showing that the differences are not a result of a single gene mutation (for example all appendages being elongated, or shortened). Proserpinicaris young, on the other hand, can be distinguished from the other three species by its exceptionally long caudal rami in both sexes (see Figure 2A,D), and it also has a significantly shorter apophysis of the male third leg than the outer spine (Figure 1B). Proserpinicaris ondali and P. wangpi have the most similarly shaped caudal 


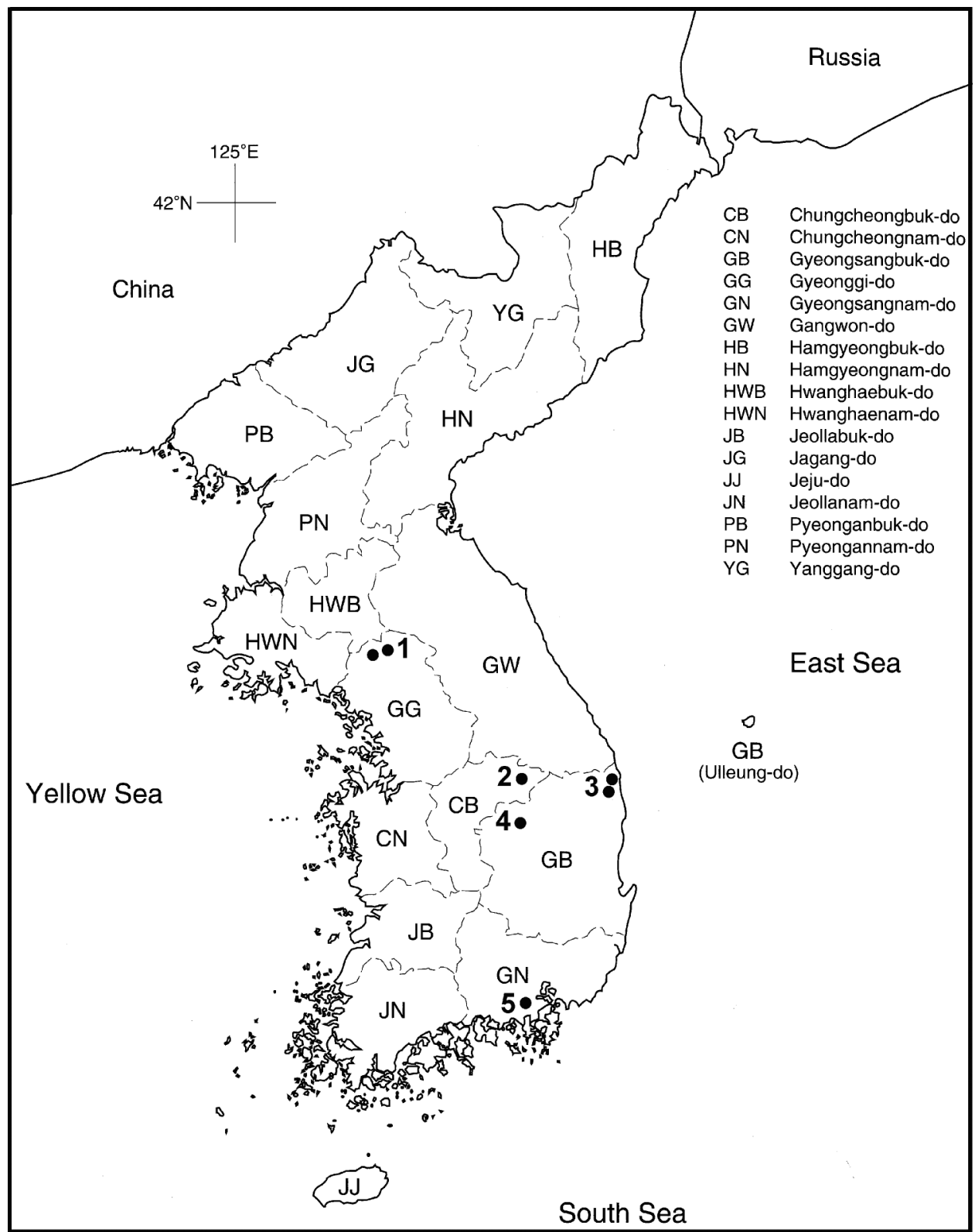

Figure 12. Distribution of the Proserpinicaris Jakobi, 1972 species in Korea: 1, P. imjin sp. nov.; 2, P. ondali (Lee and Chang, 2009); 3, P. wangpi sp. nov.; 4, P. young sp. nov.; 5, P. sp. See text for more explanation.

rami, but can be easily distinguished by the following five characters: $P$. ondali has a longer inner distal process on the male fifth leg, with the longest endopodal seta reaching only half of its length (compare fig. 5D in Lee and Chang (2009) and Figure 8B); lateral caudal setae are inserted more posteriorly in P. ondali (compare fig. 5B in Lee 
and Chang (2009) and Figure 7B); both male and female caudal rami of similar length or female rami slightly longer in $P$. ondali, whereas female caudal rami always significantly shorter than those in male in $P$. wangpi; somewhat different armature formula of both male and female antennulae (although this may be a result of different observation); and anal somite with two short ventral rows of spinules in anterior half in $P$. ondali, whereas those are always missing in $P$. wangpi. In fact, all three new Korean species described here are missing ventral spinules on the anal somite. They are present in the Japanese P. nipponensis (Chappuis, 1955) comb. nov., but this species differs from $P$. ondali by much longer caudal rami and shorter dorsal caudal seta, among other things. Miura (1969) reported $P$. nipponensis from Korea, but this record was tentatively synonymized with $P$. ondali by Lee and Chang (2009). We synonymize it with $P$. wangpi based on their morphology and the proximity of their sampling locations. The Japanese $P$. nipponensis would have to be redescribed to properly assess the level of morphological differences from the Korean congeners, as the original description by Chappuis (1955) and the redescription of females by Miura (1964) are both lacking in detail. All four Korean species are allopatric in distribution (Figure 12), and there is probably another undescribed species in the Gyeongsangnam-do province, reported from two specimens only and considered as conspecific with $P$. ondali by Lee and Chang (2009) and Chang (2010). They did not provide any illustrations of these specimens, and this population would have to be examined for microcharacters discovered in the current study, to be able to properly assess its taxonomic status. Recent combined morphological and molecular studies of short range endemics from the genus Kinnecaris Jakobi, 1972 in Australia (Karanovic and Cooper, 2011b) have shown that similar morphological differences in urosomite ornamentation, caudal rami shape, and proportions of different armature elements on the swimming legs are all indicative of distinct biological species. The group of five species from Korea and Japan is certainly a monophyletic lineage within Fontinalicaridinae, defined by the shape of the fourth leg endopod in male, which bears a scoop-like structure on the tip, formed by a bunch of basally fused apical spinules.

All five Asian species mentioned above also have a large and slender hyaline process on the anterior surface of the male fourth leg basis, between exopod and endopod, which is a synapomorphy of a larger group of species, including also the type species of the genus Proserpinicaris Jakobi, 1972, P. proserpina (Chappuis, 1938). This is a complex structure and highly unlikely to have arisen convergently a number of times, which means that recognizing the Asian species as a separate genus would render the genus Proserpinicaris paraphyletic. Type species of two genera proposed by Jakobi (1972) (Nipponicaris Jakobi, 1972, and Pannonicaris Jakobi, 1972) also share this structure, and are included here in the redefined genus Proserpinicaris, which makes these two genera junior subjective synonyms of Proserpinicaris (see above). The genus Proserpinicaris, as redefined here, is Palaearctic in distribution, with its centre of diversity in southern Europe. Besides five Asian congeners and the type species, we consider as its valid members the following 14 species: Proserpinicaris admete (Cottarelli, Fasano, Mura and Saporito, 1980) comb. nov. from Sardinia (Cottarelli et al. 1980); P. amalasuntae (Bruno and Cottarelli, 1998) comb. nov. from the mainland Italy (Bruno and Cottarelli 1998); P. cantabrica (Chappuis, 1937) from Spain (Chappuis 1937; Lang 1948); P. cruzi (Noodt and Galhano, 1969) comb. nov. from Portugal (Noodt and Galhano 1969); P. gorganensis (Kovalchuk and Kovalchuk, 1990) comb. nov. from Ukraine (Kovalchuk and Kovalchuk 1990); P. hispanica (Martínez 
Arbizu, 1997) comb. nov. from Spain (Martínez Arbizu 1997); P. ima (Cottarelli, 1989) comb. nov. from Sardinia (Cottarelli 1989); P. kalypso (Pesce, Galassi and Cottarelli, 1988) comb. nov. from Sicily (Pesce and Galassi 1987; Pesce et al. 1988); P. mangini (Rouch, 1992) comb. nov. from France (Rouch 1992); P. meridionalis (Rouch, 1990) comb. nov. from France (Rouch 1990); P. moravica (Šterba, 1965) from the Czech Republic (Šterba 1965); P. nicolasi (Rouch, 1996) comb. nov. from France (Rouch 1996); P. pannonica (Török, 1935) comb. nov. from Hungary, Romania, and Slovakia (Török 1935; Lang 1948; Damian 1958; Kulhavý 1960); and P. phyllura (Kiefer, 1938) from central and northern Europe (Kiefer 1938; Kunz 1938; Lang 1948; Noodt 1952; Kulhavý 1960; Enckell 1969; Glatzel 1990, 1992; Glatzel and Schminke 1996).

We have to point out that the description of $P$. gorganensis is severely lacking in detail (see Kovalchuk and Kovalchuk 1990), but that is a constant problem in this family (Schminke 2010), and one of the main factors that precludes a meaningful cladistic analysis based on morphological characters (Karanovic 2005; Karanovic and Cooper 2011a, b). Of the 20 species of Proserpinicaris, only probably the descriptions of $P$. amalasuntae, $P$. cruzi, $P$. hispanica, $P$. phyllura and $P$. proserina are adequate to allow recognizing potential new closely related congeners, and those of the latter two mostly thanks to some detailed redescriptions (see Kunz 1938; Noodt 1952; Bruno and Cottarelli 1998). All other species would have to be redescribed if we are to properly assess the diversity in this group and explore phenomena like short-range endemism. Some other, also technical, problems are already mentioned in the Introduction section above, as well as in the Remarks sections after the revised generic diagnosis. We speculate that the male fourth leg of P. pannonica, as illustrated by Török (1935), was probably swapped with another new species that he described in the same paper and from the same locality (Budapest, Hungary), Parastenocaris budapestiensis Török, 1935. This mix-up caused quite a few problems in the past. Lang (1948), for example, because of this, and because he relied mostly on the characters of the fourth swimming leg, placed P. budapestiensis in the proserpina-group, although it shared hardly any other morphological characters with the other four species. Similarly, he considered $P$. pannonica to be a member of the minuta-group. The same original mix-up prompted Jakobi (1972) to designate $P$. pannonica the type species of his new genus Pannonicaris Jakobi, 1972, where he additionally included four other species from the minuta-group. He also designated P. budapestiensis the type species of his new genus Lacustricaris Jakobi, 1972, where he additionally included only a completely unrelated Canadian species, Parastenocaris lacustris Chappuis, 1958. Schminke (2010) recognized that $P$. budapestiensis and $P$. lacustris are so different that he included them in two separate subfamilies, but unfortunately did not realize that by excluding the type species from the genus Lacustricaris it cannot be a valid genus any longer. We here formally synonymize Lacustricaris with Parastenocaris Kessler, 1913, and designate P. lacustris as incertae sedis in Fontinalicaridinae.

As mentioned in the Introduction section, we also do not consider Parastenocaris nolli Kiefer, 1938, and $P$. delamarei Chappuis, 1958 as members of the genus Proserpinicaris, even though they were included here by Jakobi (1972). The former species has its lateral caudal setae inserted near the posterior margin, very short fifth legs both in male and female, and relatively small spinules on the male fourth leg basis inserted medially from endopod, among many morphological differences (see Kiefer 1938, 1960a,b), and it was correctly placed in the nominotypical subfamily by Schminke (2010). Parastenocaris delamarei was also placed in the nominotypical 
subfamily by Schminke (2010). It differs from all 20 species of Fontinalicaris by the shape of the male third leg, armature of the male fourth leg basis, and insertion of lateral setae on the caudal rami (see Chappuis 1958).

Martínez Arbizu (1997) noted that his newly described Spanish species, P. hispanica, is morphologically extremely similar to the French Parastenocaris fontinalis meridionalis Rouch, 1990, and he argued that the latter is a separate species too, rather than a subspecies of $P$. fontinalis Schnitter and Chappuis, 1915. We completely agree with this view. We do not, however, share his view that $P$. hispanica and $P$. meridionalis should be considered members of the fontinalis-group. It was Karanovic (2005) who first pointed out that these two species could not be assigned to the fontinalis-group. Martínez Arbizu's (1997) phylogenetic analysis was conducted on an arbitrary group of four species and one subspecies (including Parastenocaris psammica Songeur, 1961, which has completely different fifth legs both in male and female), and without an outgroup. Although he mentioned that Parastenocaris aquaeducta Chappuis, 1925 was "considered an appropriate outgroup to polarize the characters", no characters were scored for it in his matrix, nor did it appear on the resulting cladogram. Furthermore, of the 16 scored characters six have the same state in all five taxa, and so are not phylogenetically informative for the analysis. Most curiously, he did not score for the presence/absence of a large hyaline process on the male fourth leg basis, which is an obvious morphological feature that at once distinguishes $P$. hispanica and $P$. meridionalis from the other three members, and which was used by Lang (1948) to define a completely separate group of species, the proserpina-group. Had he done so, he would have had to consider a much larger number of species in his phylogenetic analysis. It is not clear why Martínez Arbizu (1997) has chosen to compare his new species with a selected small number of species from the fontinalis-group [which had grown significantly since first proposed by Lang (1948)], and none from the proserpina-group, but we speculate that this may be because of a relatively similar shape of the male fourth leg endopod in $P$. proserpina and $P$. hispanica. Unfortunately, as we discussed above, the transformed endopod with serrulate or tuberculate margins can be found in some other unrelated taxa (see, for example, Cottarelli et al., 2000), and is either a plesiomorphic character state or a homoplasy. Most of the species of Proserpinicaris have this type of endopod, except $P$. ima, where it is completely smooth, and $P$. cruzi and $P$. cantabrica, where the endopod is pinnate (or plumose) along the inner margin. Proserpinicaris meridionalis and especially $P$. hispanica show a number of plesiomorphic characters in the genus, including the inner spinules on the male fourth leg coxa, long spinule (or small seta?) on the posterior surface of the fifth leg at the base of the basal seta, long and basally placed tubular pore on the inner margin of the first exopodal segment of the male third leg, and relatively small hyaline process on the male fourth leg basis (at least in comparison with other species). We should mention here that there is a possibility that Martínez Arbizu (1997) overlooked at least one species in the P. hispanica complex, which we induce from his drawings of the female leaf-like caudal rami and male anal somite with ventral spinules in a specimen from Sta. Rouch 1978 no. 8 (see his figs 6B, 7B).

Schminke (2010) added further to the problem, by providing a series of drawings of the typical Parastenocaridinae and Fontinalicaridinae, without any reference to their specific identity, origin of the material, or its deposition. Although, he did not say it specifically, reading through his paper one may be led to think that his 
fig. 2D is of $P$. fontinalis, although it has a large hyaline process on the anterior surface of the male fourth leg basis, i.e. looks very much like that of $P$. hispanica. This could be quite accidental, but we should mention here that in the original description of $P$. fontinalis by Schnitter and Chappuis (1915), all subsequent redescriptions (Noodt 1952; Kiefer 1959; Kulhavý 1961; Songeur 1961; Dussart 1966), and even in the description of a separate subspecies (Kiefer 1960c) the male fourth leg basis is completely smooth. Although it is beyond the scope of this paper to formally redefine the genus Fontinalicaris Jakobi, 1972, we can suggest that at least the following six taxa form a morphologically compact and probably monophyletic group with $F$. fontinalis (Schnitter and Chappuis, 1915), its type species: F. bohemica (Šterba, 1968) comb. nov. from the Czech Republic (Šterba 1968); F. chappuisi (Serban, 1960) comb. nov. from Romania (Serban 1960); F. fontinalis borea (Kiefer, 1960) from Germany (Kiefer 1960c); F. kabyloides (Enckell, 1965) comb. nov. from Spain (Enckell 1965); F. ruffoi (Chappuis, 1954) comb. nov. from Italy (Chappuis 1954); and F. torokae (Ponyi, 1957) from Hungary (Ponyi 1957). Fontinalicaris bohemica was synonymized with $F$. fontinalis by Martínez Arbizu (1997), which we are reluctant to follow in the light of discovering short-range endemism in this group more as a rule than as an exception (this study; Karanovic and Cooper, 2011a, b). We are in complete agreement with Martínez Arbizu's (1997) view that Parastenocaris phyllophora Noodt, 1954 is not at all closely related to Fontinalicaris fontinalis, although it was included in the genus Fontinalicaris by Jakobi (1972) as its only other member in addition to the type species. Actually, $P$. phyllophora had already been considered a synonym of $P$. italica Chappuis, 1935 by Chappuis $(1958,1959)$ and Kiefer $(1963,1969)$, but the latter was designated by Jakobi (1972) as the type species of another genus, Italicocaris Jakobi, 1972. This is probably one of the best illustrations of the superficial nature of the family revision performed by Jakobi (1972), and the problems we have to deal with while reinstating and redefining his genera. There is no question that the genera Proserpinicaris and Fontinalicaris are relatively closely related, but so are some other Fontinalicaridinae. For example, the South American genus Brasilibathynellocaris Jakobi, 1972 has the same pattern of urosomal cuticular windows, insertion of the lateral caudal setae, inner coxal spinules on the male fourth leg, fifth legs with minimal sexual dimorphism, and even relatively similar structure of the male third leg, but differs from Proserpinicaris and Fontinalicaris by the transformation of the first exopodal segment on the male fourth leg (see Noodt, 1962)

The genus Proserpinicaris, as redefined here, is Palaearctic in distribution, with its centre of diversity in southern Europe. A key to species has not been compiled before, but with the addition of the three new species described in this paper it already numbers 20 congeners.

\section{Key to species of Proserpinicaris}

1. Hyaline process on the fourth leg basis in male significantly shorter than

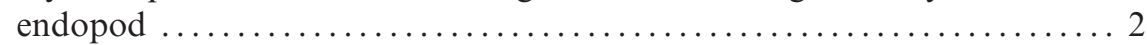
This process as long as, or longer than endopod $\ldots \ldots \ldots \ldots \ldots \ldots \ldots$

2. Inner margin of fourth leg endopod in male smooth distally ......... 3 This margin plumose ...... P. cruzi (Noodt and Galhano, 1969) comb. nov. 
3. Fourth leg endopod extremely inflated in proximal half, wider than exopod........................ P. nicolasi (Rouch, 1996) comb. nov. Fourth leg endopod much more slender than exopod .............. 4

4. Third leg apophysis in male inflated distally

P. hispanica (Martínez Arbizu, 1997) comb. nov. Apophysis wider in proximal than in distal half

P. meridionalis (Rouch, 1990) comb. nov.

5. Fourth leg endopod in male with crown of fused spinules, forming scoop-like

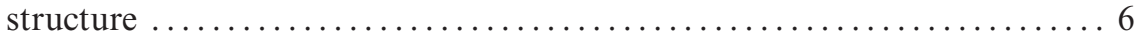

Endopod with pointed tip, without scoop-like structure $\ldots \ldots \ldots \ldots \ldots 10$

6. Anal somite with two ventral rows of spinules $\ldots \ldots \ldots \ldots \ldots \ldots \ldots \ldots$

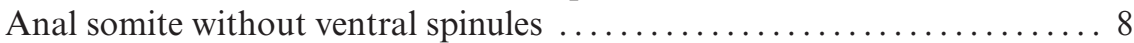

7. Caudal rami more than six times as long as wide; dorsal caudal seta not longer than inner apical seta ......... P. nipponensis (Chappuis, 1955) comb. nov. Caudal rami about five times as long as wide; dorsal caudal seta twice as long as inner apical seta .......... P. ondali (Lee and Chang, 2009) comb. nov.

8. Female caudal rami leaf-like; male caudal rami slightly inflated posteriorly in

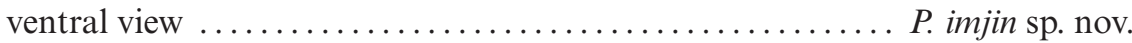
Both female and male caudal rami cylindrical ................. 9

9. Male caudal rami about six times as long as wide ......... P. young sp. nov. Male caudal rami about 4.3 times as long as wide ....... P. wangpi sp. nov.

10. Fourth leg endopod in male pinnate along inner margin

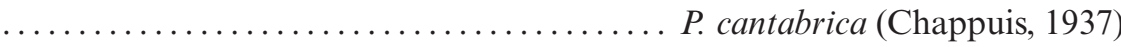

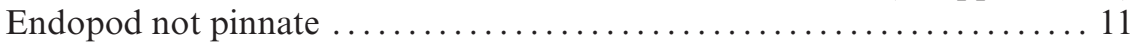

11. Third leg exopodal spine in male inflated distally $\ldots \ldots \ldots \ldots \ldots \ldots \ldots 12$

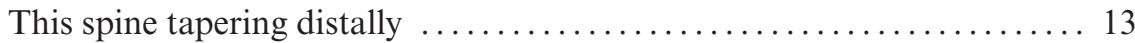

12. Fourth leg endopod in male completely smooth and very slender P. ima (Cottarelli, 1989) comb. nov. Endopod with serrated outer margin ....... P. admete (Cottarelli, Fasano, Mura and Saporito, 1980) comb. nov.

13. Fourth leg endopod in male serrated in proximal half, smooth distally ...... P. kalypso (Pesce, Galassi and Cottarelli, 1988) comb. nov.

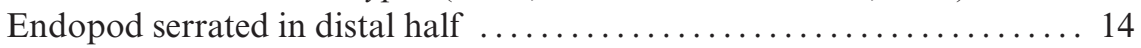

14. Fourth leg endopod in male smooth proximally, serrated at least on one mar-

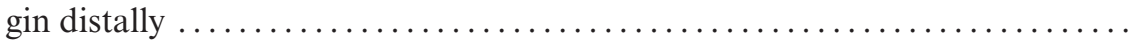
15

Endopod with proximal half serrated at least on one side, or with

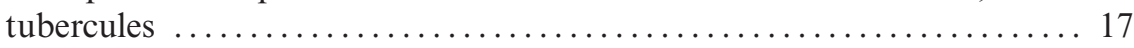

15. Fourth leg endopod serrated along inner margin distally $\ldots \ldots \ldots \ldots \ldots 16$

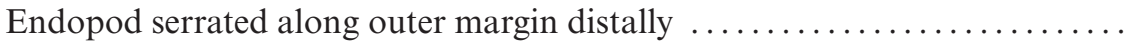
........... P. gorganensis (Kovalchuk and Kovalchuk, 1990) comb. nov. 
16. Caudal rami cylindrical ........... P. pannonica (Török, 1935) comb. nov. Caudal rami leaf-like .................... P. phyllura (Kiefer, 1938)

17. Third leg in male with two prominent beaks on inner margin of first exopodal

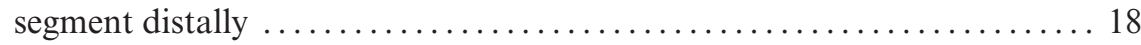
This segment with smooth and concave inner margin distally ........ 19

18. Fourth leg endopod as long as basal hyaline process, lanceolate, with sharp tip............. P. amalasuntae (Bruno and Cottarelli, 1998) comb. nov. Endopod shorter than basal hyaline process, with minute slender seta apically......................... proserpina (Chappuis, 1938)

19. Third leg apophysis in male very short, as wide as long; anal operculum with straight posterior margin .......... P. mangini (Rouch, 1992) comb. nov. Apophysis longer than wide; anal operculum very convex and long ........

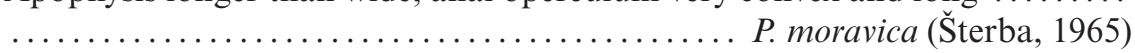

\section{Acknowledgements}

Ms Renate Walter, Zoologisches Museum Hamburg, is kindly acknowledged for the help in preparation of the scanning electron micrographs. Financial support to the senior author came from Brain Pool and NIBR grants (both in Korea), while the necessary facilities were provided by the Zoologisches Museum in Hamburg and Hanyang University in Seoul.

\section{References}

Berera R, Cottarelli V. 2003. Two new species of interstitial harpacticoids from southern Italy and proposal of a new Parastenocaris species-group. Ital J Zool. 70:261-268.

Boxshall GA, Halsey SH. 2004. An introduction to copepod diversity. London: The Ray Society. $966 \mathrm{pp}$.

Boxshall GA, Jaume D. 2000. Making waves: the repeated colonization of freshwater by copepod crustaceans. Adv Ecol Res. 31:61-79.

Bruno MC, Cotarelli V. 1998. Description of Parastenocaris amalasuntae sp. nov. and new data on Parastenocaris proserpina and Parastenocaris pasquinii from subterranean waters of central Italy (Copepoda, Harpacticoida). Ital J Zool. 65:121-136.

Chang CY. 2010. Continental Harpacticoida. Seoul: Invertebrate Fauna of Korea, 21(4), National Institute of Biological Resources. $244 \mathrm{pp}$.

Chappuis PA. 1937. Subterrane Harpacticoiden aus Nord-Spanien. Bull Soc Sci Cluj, Roumanie 8:556-571.

Chappuis PA, 1954. Nouveaux harpacticoides de la nappe phreatique de L'Adige. Mem Mus Civ St Nat Verona 4:157-162.

Chappuis PA. 1955. Harpacticoides troglobies du Japon. Notes Biospéol. 10:183-190.

Chappuis PA. 1958. Le genre Parastenocaris Kessler. Vie Milieu 8:423-432.

Chappuis PA. 1959. Biogeographie du genre Parastenocaris. Vie Milieu 9:444-453.

Chappuis PA, Delamare Deboutteville C. 1958. Recherches sur la faune interstitelle littorale du lac Érié, Le problem des glaciations Quaternaires. Vie Milieu 8:366-376.

Corgosinho PHC, Martínez Arbizu P. 2005. Two new interstitial species of Remaneicaris Jakobi (Copepoda, Harpacticoida, Parastenocarididae) from the Ribeirão do Ouro River, Brazil, with a redefinition of the genus. Senckenber Biol 85:147-162.

Corgosinho PHC, Martínez Arbizu P, dos Santos-Silva EN. 2007. Three new species of Remaneicaris Jakobi, 1972 (Copepoda, Harpacticoida, Parastenocarididae) from the 
Ribeirão do Ouro River, Minas Gerais, Brazil, with some remarks on the groundpattern of the Parastenocarididae. Zootaxa 1437:1-28.

Corgosinho PHC, Martínez Arbizu P, dos Santos-Silva EN. 2010. Revision of Brasilibathynellocaris Jakobi, 1972 (Copepoda: Harpacticoida: Parastenocarididae) with redefinition of the genus. Zool J Linn Soc 159:527-566.

Cottarelli V. 1989. Un nuovo arpacticoide (Crustacea, Copepoda) freatobio dell'Isola la Maddalena (Sardegna): Parastenocaris ima sp. nov. Ann Mus Civ St Nat Genova 87:285-296.

Cottarelli V, Bruno MC, Berera R. 2000. Parastenocaris corsica sp. nov. and Parastenocaris silvana sp. nov., first Parastenocarididae from groundwater of Corsica (Copepoda, Harpacticoida). Crustaceana 73:345-364.

Cottarelli V, Bruno MC, Berera R. 2006. A new species of Parastenocaris from Mindoro Island, Philippines: Parastenocaris distincta sp. nov. (Crustacea: Copepoda: Harpacticoida: Parastenocarididae). Zootaxa 1368:57-68.

Cottarelli V, Bruno MC, Berera R. 2007. Interstitial harpacticoids from groundwater in Tuscany (Central Italy): Parastenocaris reidae sp. nov., Nitocrella ensifera sp. nov., and notes on the morphology of Parastenocaris cf. glacialis Noodt (Crustacea: Copepoda). Ital J Zool. 74:83-99.

Cottarelli V, Bruno MC, Berera R. 2008. Two new species of Parastenocaris (Copepoda, Harpacticoida, Parastenocarididae) from groundwater of Sardinia and Sicily. Crustaceana 81:537-555.

Cottarelli V, Bruno MC, Berera R. 2010. First record of Parastenocarididae from Thailand and description of a new genus (Copepoda: Harpacticoida). J Crust Biol. 30:478-494.

Cottarelli V, Fasano L, Mura G, Saporito PE. 1980. Parastenocaris adméte sp. nov. (Crustacea, Copepoda, Harpacticoida) di acque intersititali di Sardegna. Riv Idrobiol. 19: 619-628.

Culver D, Pipan T. 2009. The biology of caves and other subterranean habitats. Oxford: Oxford University Press. 256 pp.

Damian A. 1958. Cercetări Hidrobiologice în conducta de apă a oraşului Bucureşti, Nota II. Cu privire special asupra copepodelor. Stud Cerc Biol, ser Biol Anim. 10:177-198.

Dussart B, Defaye D. 1990. Répertoire mondial des crustacés copépodes des eaux intérieures, III. Harpacticoïdes. Leiden: Brill, Crustaceana suppl 16. 384 pp.

Dussart BH. 1966. Copépodes de la faune bentique du Léman. Vie Milieu 17:283-302.

Dussart BH. 1979. Algunos copepodos de America del Sur. Publ Ocas Mus Nac Hist Nat, Santiago 30:1-13.

Enckell PH. 1965. New harpacticoids from Spain. Acta Univ Lund, sect II, vol 1965, 19:1-9.

Enckell PH. 1969. Distribution and dispersal of Parastenocarididae (Copepoda) in northern Europe. Oikos 20:493-507.

Frakes LA. 1999. Evolution of Australian environments. Flora of Australia (2nd ed.), 1, p. 163-203.

Galassi DMP, De Laurentiis P. 2004. Towards a revision of the genus Parastenocaris Kessler, 1913: establishment of Simplicaris gen. nov. from groundwaters in central Italy and review of the P. brevipes-group (Copepoda, Harpacticoida, Parastenocarididae). Zool J Linn Soc. 140:417-436.

Glatzel T. 1990. On the biology of Parastenocaris phyllura Kiefer (Copepoda, Harpacticoida). Stygologia 5:131-136.

Glatzel T. 1992. Beschreibung der sechs Nauplius-Stadien von Parastenocaris phyllura Kiefer, 1938 im Vergleich mit P. vicesima Klie, 1935 (Copepoda, Harpacticoida). Bijdr Dierk. 61:185-191.

Glatzel T, Schminke HK. 1996. Mating behaviour of the groundwater copepod Parastenocaris phyllura Kiefer, 1938 (Copepoda: Harpacticoida). Contr Zool. 66:103-108. 
Humphreys WF. 2000. Background and glossary. In: Wilkens H, Culver DC, Humphreys WF. Ecosystems of the World, 30, Subterranean ecosystems. Amsterdam (The Netherlands): Elsevier. p. 3-14.

Huys R. 2009. Unresolved cases of type fixation, synonymy and homonymy in harpacticoid copepod nomenclature (Crustacea: Copepoda). Zootaxa 2183:1-99.

Huys R, Boxshall GA. 1991. Copepod evolution. London: The Ray Society. 468 pp.

ICZN. 1999. Fourth edition. London: The International Trust for Zoological Nomenclature.

Jakobi H. 1969. Forficatocaris noodti n. gen., sp. nov. (Copepoda, Harpacticoidae) aus brasilianischem Limnopsammal. Crustaceana 17:231-238.

Jakobi H. 1972. Trends (Enp.P4 Mänchen) innerhalb der Parastenocarididen (Copepoda Harpacticoidea). Crustaceana 22:127-146.

Karanovic T. 2004. Subterranean Copepoda from arid Western Australia. Leiden: Brill, Crustaceana Monographs 3. 366 pp.

Karanovic T. 2005. Two new subterranean Parastenocarididae (Crustacea, Copepoda, Harpacticoida) from Western Australia. Rec W Austr Mus. 22:353-374.

Karanovic T. 2006. Subterranean Copepods (Crustacea, Copepoda) from the Pilbara Region in Western Australia. Rec W Austr Mus. suppl. 70:1-239.

Karanovic T, Bobic M. 1998. Two new species of Copepoda Harpacticoida from east Serbia (Balkan Peninsula): Parastenocaris serbica sp. n. and Bryocamptus (R.) borus sp.n. Crustaceana 71:171-184.

Karanovic T, Cooper SJB. 2011a. Third genus of parastenocarid copepods from Australia supported by molecular evidence (Harpacticoida: Parastenocarididae). Leiden: Brill, Crustaceana Monographs 16:293-337.

Karanovic T, Cooper SJB. 2011b. Molecular and morphological evidence for short range endemism in the Kinnecaris solitaria complex (Copepoda: Parastenocarididdae) with descriptions of seven new species. Zootaxa 3026:1-64.

Kiefer F. 1938. Neue harpacticoide Ruderfusskrebse (Crust. Cop.) aus dem Grundwasser von Aschaffenburg (Main). Zool Anz. 123:142-147.

Kiefer F. 1959. Unterirdisch lebende Ruderfusskrebse vom Hochrhein u. Bodensee. Beitr naturk Forsch Südwestdeutsch. 18:42-52.

Kiefer F. 1960a. Subterrane Ruderfusskrebse (Crust. Cop.) aus dem Ruhrtal. Zool Anz. 165:323-329.

Kiefer F. 1960b. Beiträge zur Copepodenkunde (XX). Zool Anz. 165:37-45.

Kiefer F. 1960c. Psammobionte Ruderfusskrebse (Crust. Cop.) aus dem Gebiet der Unterweser und von der Insel Helgoland. Zool Anz. 165:29-37.

Kiefer F. 1963. Über einige Copepoda Harpacticoida aus Grabungen an norditalienischen Fliessgewässern. Mem Mus Civ St Nat Verona 11:1-10.

Kiefer F. 1969. Subterrane Cyclopoida und Harpacticoida (Crustacea Copepoda) aus Norditalien. Mem Mus Civ St Nat Verona 16:157-198.

Kiefer F. 1976. Ruderfusskrebse (Crustacea, Copepoda) aus dem Sandlückensystem einiger Bäche der Ostalpen. Beitr Naturkun Forsch Südwestdeutsch. 35:111-118.

Kovalchuk NE, Kovalchuk AA. 1990. A new species of the family Parastenocaridae (Copepoda) from the Carpathian Gorgany Mountain Range. Vestn Zool. 3:75-78. [in Russian, with English abstract]

Kulhavý V. 1960. I. Beitrag zur Kenntnis der Crustaceenfauna tschechoslowakischer Grundgewässer. Acta Soc Zool Bohemoslov. 24:287-307. [in Czech, with German summary]

Kulhavý V. 1961. Über das Vorkommen der west- und osteuropäischen Elemente in der Crustaceenfauna der bohmischen unterirdischen Gewässer. Acta Soc Zool Bohemoslov. 25:297-301.

Kunz H. 1938. Harpacticoiden vom Sandstrand der Kurischen Nehrung. Studein an marinen Copepoden, III. Kiel Meersf. 3:148-157. 
Lang K. 1948. Monographie der Harpacticiden. Stockholm: Nordiska-Bokhandeln, 2 volumes. $1682 \mathrm{pp}$.

Lee JM, Chang CY. 2009. Two groundwater copepods of the genus Parastenocaris (Harpacticoida, Parastenocarididae) from South Korea. Anim Cell Syst. 13:169-178.

Martínez Arbizu P. 1997. Parastenocaris hispanica sp. nov. (Copepoda: Harpacticoida: Parastenocarididae) from hyporheic groundwaters in Spain and its phylogenetic position within the fontinalis-group of species. Contrib Zool. 66:215-226.

Martínez Arbizu P, Moura G. 1994. The phylogenetic position of the Cylindropsyllinae Sars (Copepoda, Harpacticoida) and the systematic status of the Leptopontiinae Lang. Zool Beitr. 35:55-77.

Miura Y. 1964. Subterranean harpacticoid copepods from a driven well in Japan. Jap J Zool 14:133-141.

Miura Y. 1969. Results of the speleological survey of South Korea 1966, XIV. Subterranean harpacticoid copepods of South Korea. Bull Nat Sci Mus Tokyo, Ser A, Zool. 12:241-254.

Noodt W. 1952. Subterrane Copepoden aus Norddeutschland. Zool Anz. 148:331-343.

Noodt W. 1962. Limnisch-subterrane Copepoden der Gattung Parastenocaris Kessler aus Mittelamerika. In: Titschack E, Koepcke HW, editors. Beiträge zur neotropischen Fauna 2. Jena: VEB Gustav Fischer Verlag. p. 223-248.

Noodt W. 1963. Subterrane Crustaceen der zentralen Neotropis. Zool Anz. 171:114-147.

Noodt W. 1972. Drei neue Parastenocaris aus Kolumbien (Crustacea Copepoda), 1. Mitteilung über kolumbianische Grundwasser-Crustaceen. Stud Neotr Fauna 7:101-112.

Noodt W, Galhano MH. 1969. Studien an Crustacea Subterranea (Isopoda, Syncarida, Copepoda) aus dem Nordern Portugals. Publ Inst Zool "Dr. Augusto Nobre" Fac Ciê Porto 107:1-75.

Pesce GL, Galassi DP. 1987. Copepodi di acque sotterranee della Sicilia. Animalia 14:193-235.

Pesce GL, Galassi DP, Cottarelli V. 1988. First representative of the family Parastenocarididae from Sicily (Italy), and description of two new species of Parastenocaris Kessler (Crustacea Copepoda: Harpacticoida). Bull Zoöl Mus Univ Amsterdam 11:137-144.

Playford P. 2003. The Permo-Carboniferous glaciations of Gondwana: its impact on Western Australia. West Wildlife 7:1-5.

Ponyi E. 1957. Parastenocaris Törökae sp. n., eine neue Copepoden-Art aus Ungarn. Opusc Zool Inst Zoosyst Univ Budapest. 2:43-47.

Por FD, Hadel VF. 1986. Two new species of Attheyella (Copepoda: Harpacticoida: Canthocamptidae) from bromeliads of the Serra da Juréia (São Paulo, Brazil). J Crust Biol. 6:777-788.

Ranga Reddy Y. 2001. Discovery of Parastenocarididae (Copepoda, Harpacticoida) in India, with the description of three new species of Parastenocaris Kessler, 1913, from the River Krishna at Vijayawada. Crustaceana 74:705-733.

Ranga Reddy Y, Defaye D. 2007. Parastenocarididae (Crustacea, Copepoda, Harpacticoida) of India: description of Parastenocaris mahanadi sp. nov., and redescription of $P$. curvispinus Enckell, 1970 from hyporheic habitats. Zootaxa 1580:1-26.

Ranga Reddy Y, Defaye D. 2009. Two new Parastenocarididae (Copepoda, Harpacticoida) from India: Parastenocaris muvattupuzha sp. nov. from a river and $P$. kotumsarenis sp. nov. from a cave. Zootaxa 2077:31-55.

Reid JW. 1994. Murunducaris juneae, new genus, new species (Copepoda: Harpacticoida: Parastenocarididae) from wet campo in central Brazil. J Crust Biol. 14:771-781.

Reid JW. 1995. Redescription of Parastenocaris brevipes Kessler and description of a new species of Parastenocaris (Copepoda: Harpacticoida: Parastenocarididae) from the U.S.A. Can J Zool. 73:173-187.

Rouch R. 1990. Deux nouvelles Parastenocaris (Copépodes, Harpacticoïdes) des Pyrénées. Ann Limnol. 26:19-28. 
Rouch R. 1992. Parastenocaris mangini sp. nov., nouvel harpacticoïde (Copépodes) stygobie des Pyrénées. Crustaceana 63:306-312.

Rouch R. 1996. Une nouvelle espéce de Parastenocaris (Copépodes, Harpacticoïdes) du sudouest de la France. Crustaceana 69:41-46.

Schminke HK. 1976. Systematische Untersuchungen an Grundwasserkrebsen eine Bestandsaufnahme (mit der Beschreibung zweier neuer Gattungen der Familie Parabathynellidae, Bathynellacea). Intern J Speleol. 8:195-216.

Schminke HK. 1991. Sexual dimorphism in caudal rami of Parastenocarididae (Copepoda: Harpacticoida). Proceedings of the Fourth International Conference on Copepoda; Bull Plank Soc Japan, Spec. Vol.: 573-584.

Schminke HK. 2008. First record of groundwater fauna from Papua New Guinea: Kinnecaris Jakobi, 1971 redefined (Copepoda, Harpacticoida, Parastenocarididae), and description of a new species. Crustaceana 81:1241-1253.

Schminke HK. 2009. Monodicaris gen. n. (Copepoda, Harpacticoida, Parastenocarididae) from West Africa. Crustaceana 82:367-378.

Schminke HK. 2010. High-level phylogenetic relationships within Parastenocarididae (Copepoda, Harpacticoida). Crustaceana 83:343-367.

Schnitter H, Chappuis PA. 1915. Parastenocaris fontinalis nov. spec., ein neuer Süsswasserharpacticide, Zugleich ein Beitrag zur Kenntnis der Gattung Parastenocaris Kessler. Zool Anz. 45:290-302.

Serban M. 1960. Notes sur les Copépodes, Description de Parastenocaris chappuisi sp. nov. nouvel harpacticide phréatobie de la côte roumaine de la Mer Noire. Ann Spéléol. 15:117-126.

Songeur M. 1961. Un nouveau Copépode psammique de Lorraine. Vie Milieu 12:483-496.

Šterba O. 1965. Über eine neue Parastenocaris-Art (Copepoda, Harpacticoidae) aus Mähren. Zool Anz. 175:204-208.

Šterba O. 1968. Parastenocaris bohemica sp. n. (Harpacticoidea) aus Böhmen. Crustaceana, supplement 1, Studies on Copepoda: 61-64.

Stock JK, von Vaupel Klein JC. 1996. Mounting media revisited: the suitability of Reyne's fluid for small crustaceans. Crustaceana 69:749-798.

Török P. 1935. Filtrat-Fauna der Budapester Wasserleitung. Mat Termész Ert, Budap. 53:637-664. [in Hungarian, with German summary]

Wells JBJ. 2007. An annotated checklist and keys to the species of Copepoda Harpacticoida. Zootaxa 1568:1-872. 
